\title{
Contributions
}

Donatella Baiardi*

\section{Technological Progress and the Environmental Kuznets Curve in the Twenty Regions of Italy}

\begin{abstract}
The paper explores the relationship between per capita income and three air pollutants, CO, NMVOCs, and $\mathrm{SO}_{x}$, using a novel dataset based on the 20 regions of Italy. Given the central role of technological progress in long-term environmental problems, we empirically investigate the influence of innovation on the environmental Kuznets curve (EKC). The estimation results validate the existence of an EKC for the three air pollutants considered. Furthermore, the influence of innovation on the inverse-U-shaped curve identified by the theoretical literature is in general empirically confirmed. Finally, the same conclusions also hold when using another dataset related to the aggregate national economy rather than separate regions.
\end{abstract}

Keywords: air pollutants, environmental Kuznets curve, Italian regions, technological progress

JEL Classification: O30, Q53, Q58

DOI 10.1515/bejeap-2013-0120

\section{Introduction}

The environmental Kuznets curve (EKC) describes an inverse U-shaped relationship between pollution and per capita income. Grossman and Krueger (1991) were the first to collect this evidence, which was defined as the EKC in the light of its similarity with the inverse-U-shaped relationship between per capita income and inequality studied by Kuznets (1955). The intuition behind the EKC is very appealing: during the early stage of development, when the level of per

*Corresponding author: Donatella Baiardi, Department of Economics, Quantitative Methods and Business Strategies, University of Milano-Bicocca, Piazza dell'Ateneo Nuovo, Building U6, Room 3055, I20126 Milano, Italy, E-mail: donatella.baiardi@unimib.it 
capita income is low and the economy is being revolutionized by the process of industrialization, pollution tends to increase rapidly and have negative consequences on environmental quality. Later, when higher standard of living is achieved (post-industrial economy or service economy), the trend tends to reverse. There are many reasons. Higher levels of education and access to information raise the awareness of the importance of a clean environment and the willingness to pay for its preservation (Selden and Song 1994). Furthermore, as noted by Komen, Gerking, and Folmer (1997), richer countries can afford higher investment in R\&D in order to substitute more polluting obsolete technologies with new upgraded ones. In addition, innovation can also encourage the more efficient use of natural resources, fostering investment in green technology (Ghisetti and Quatraro 2013). These factors play an important role in policy making. Developed economies in fact exhibit stricter environmental regulations and promote abatement policies, so that pollution levels tend to decline.

The EKC has been widely investigated in the last 30 years in the empirical environmental literature, mainly through pooled panel data of different sets of countries. Findings are mixed, and the debate on the validity of the EKC and its main determinants is still open. There are many surveys summing up the empirical evidence, see for example Stern (1998, 2004) and Dinda (2004). It is worth noting that the EKC hypothesis is traditionally investigated from an empirical point of view. Theoretical studies are less frequent, and they usually conclude that the EKC is closely related to the role of technological progress. For example, Andreoni and Levinson (2001) provide a microfoundation of the EKC by means of a straight-forward static model, where the EKC directly depends on the technological link between consumption of a desired good and abatement of any undesirable byproduct. Chimeli and Braden (2005) demonstrate that differences across units in Total Factor Productivity (TFP) produce a cross-sectional EKC and that this variable exhibits a critical value such that higher TFPs are associated with better environmental quality. Brock and Taylor (2010) find that the EKC is the result of the convergence to a sustainable growth path when technological progress in abatement is introduced into the Solow model. Chimeli (2007) and Smulders, Bretschger, and Egli (2011) show that technological progress is a very complex phenomenon whose effects on the relationship between economic growth and the environment are not easily identified.

To the best of our knowledge, notwithstanding the key role of technology in the EKC framework, innovation is seldom explicitly introduced as a control variable in the empirical literature. It is generally represented by proxies like energy consumption, which proves to be the main cause of $\mathrm{CO}_{2}$ emissions in Ang (2007), Iwata, Okada, and Samreth (2010), Iwata, Okada, and Samreth (2012), 
and Nasir and Rehman (2011). The aim of this paper is to study empirically for first time the role of innovation in the inverse-U-shaped relationship between per capita income and pollution. If the EKC holds, there are in fact different aspects of innovation which affect both the distance and the speed with which an economy moves toward the turning point (Chimeli 2007), i.e. the point on the EKC where environmental quality begins to improve as per capita income continues to increase. Starting from Leitão (2010), who studies the role of corruption in the EKC using a cross-national panel of countries, we first estimate the effects of innovation on per capita income, which may indirectly influence the EKC. We then propose an extension of the alternative specification of the EKC model developed by Bradford et al. (2005), in order to check (i) the validity of the EKC hypothesis and (ii) the role of innovation on the turning point of the EKC. Moreover, as in Bradford et al. (2005), the new formulation of the EKC proposed in this paper overcomes some technical problems caused by nonlinear transformations of potentially non-stationary variables that typically affect the canonical specification of the EKC.

The empirical analysis is performed on three air local pollutants, CO (carbon monoxide), NMVOCs (non-methane volatile organic compounds), and $\mathrm{SO}_{x}$ (sulfur oxides) ${ }^{1}$ using a new panel dataset on the 20 regions of Italy. ${ }^{2}$ From an environmental point of view, the case of Italy is of particular interest for many reasons. As noted in a very recent paper by Ghisetti and Quatraro (2013), greenhouse gas emissions in Italy are higher than in other G8 countries and exhibit strong and persistent regional differences. They also highlight that technological progress varies considerably across the country (for more details, see also Leonida, Petraglia, and Murillo-Zamorano 2004; Bianchi and Menegatti 2008; and Mazzanti, Montini, and Zoboli 2008). These peculiarities moreover justify the choice to conduct the empirical analysis at regional level. Furthermore, to the best of our knowledge, few papers in the single country literature investigate the EKC hypothesis for the selected pollutants. In fact, the cases of CO and NMVOCs are not frequently studied since time series data are generally too short (Carson, Jeon, and McCubbin 1997; Roca et al. 2001; and Khanna 2002). For $\mathrm{SO}_{x}$, the EKC is identified by List and Gallet (1999) and Millimet, List, and Stengos

1 We indicate as $\mathrm{SO}_{x}$ the sum of $\mathrm{SO}_{2}$ (sulfur dioxide) and $\mathrm{SO}_{3}$ (sulfur trioxide).

2 CO and NMVOCs contribute to the formation of tropospheric ozone, which indirectly affects human and animal health and vegetation (European Commission 1999). CO is also caused by burning forests and other forms of combustion. NMVOC emissions are directly related to the use of organic solvents and contribute to the formation of photo-oxidants and photochemical smog. $\mathrm{SO}_{x}$ emissions produce sulfate aerosols in the troposphere. This pollutant originates from the combustion of sulfur-containing fuels, such as coal and oil, and the extraction of gasoline from oil. Volcanic eruptions are another important source of $\mathrm{SO}_{x}$ emissions. 
(2003) in the 50 US States, Roca et al. (2001) in Spain, and Fodha and Zaghdoud (2010) in Tunisia. ${ }^{3}$

The rest of the paper proceeds as follows. Section 2 reviews the EKC literature, with a special focus on single country studies. Section 3 presents the model, and Section 4 describes the data used in the estimations. Section 5 discusses the estimation results and the main robustness checks implemented. Section 6 proposes an additional analysis of the case of Italy and some stylized facts about the EKC. Section 7 concludes the paper with some policy recommendations.

\section{A literature review}

Grossman and Krueger (1991) collected for the first time evidence of the EKC for sulfur dioxide $\left(\mathrm{SO}_{2}\right)$ and dark matter (smoke). They found that three phenomena determine the nature of the relationship between income and environmental degradation: scale effects, composition effects, and technology sophistication. Scale effects are related to the increasing volume of production over time. Higher output requires more inputs, including natural resources, and thus leads to deterioration of the environment. Composition and technological effects concern the positive influence of development on environmental quality. Economic growth entails a transformation from agriculture to industry and finally to services (composition effects). During the first phase, from agriculture to industry, there is a deterioration of environmental conditions caused by increased pollution from industrial production, but in the next phase, the evolution toward services reduces pollution. Finally, technological effects make production techniques more advanced, and there is more focus on abatement, with the adoption of newer and cleaner technologies. A large number of studies widen and investigate these findings: for example, Shafik and Bandyopadhyay (1992), Selden and Song (1994) and then again Grossman and Krueger (1995) confirm the EKC hypothesis for many different pollutants.

$3 \mathrm{CO}_{2}$ is often studied in the single country literature. It is classified as a "global pollutant" because it causes problems on global scale with consequences in terms of global warming across time and nations. Given data availability (time series of $\mathrm{CO}_{2}$ are available at country level for many years, usually starting from the 1960s) and the nature of this pollutant, Friedl and Gezner (2003) state that a time series analysis is more appropriate than a panel data approach (See also Aldy 2005; Ang 2007; Cialani 2007; Akbostanc1, Türüt-Asik, and Tunç 2009; Jalil and Mahmud 2009; Iwata, Okada, and Samreth 2010; Iwata, Okada, and Samreth 2012; and Nasir and Rehman 2011). 
The traditional empirical specification of the EKC uses a pollutant as the dependent variable. The main independent variable is per capita income, which is expressed in level, in square and eventually in cubic form, in order to identify any possible functional form which differs from the canonical EKC. Bradford et al. (2005) have recently proposed a new and more robust specification of the EKC, which overcomes problems caused by nonlinear transformations of potentially non-stationary variables in panel estimation (per capita income has often a unit-root behavior). The new specification also avoids the cross-sectional dependence caused by the presence of non-stationary variables. ${ }^{4}$ Other control variables, which can explain the dynamics of environmental degradation and wealth, can be introduced. ${ }^{5}$

Nowadays an increasing body of papers analyzes the validity of the EKC hypothesis for a single nation. Table 1 provides a chronological list of the single country EKC studies. The columns report the name(s) of the author(s), the country, and the estimated functional forms. The EKC hypothesis holds for $\mathrm{NO}_{x}$ and $\mathrm{SO}_{2}$ in the 50 US States according to List and Gallet (1999) and Millimet, List, and Stengos (2003). Evidence of the EKC for $\mathrm{SO}_{2}$ is collected in Spain (Roca et al. 2001) and United Kingdom (Fosten, Morley, and Taylor 2012). The inverse-U-shaped relationship between environmental degradation and per capita income is also verified for $\mathrm{CO}_{2}$ in the United States (Aldy 2005), France (Ang 2007 and Iwata, Okada, and Samreth 2010), and United Kingdom (Fosten, Morley, and Taylor 2012). Using microdata Kahn (1998) tests successfully the EKC for vehicle hydrocarbon emissions and median household income in California. To our knowledge, the EKC hypothesis in developing countries has only recently been studied: it is observed only for $\mathrm{SO}_{2}$ in Tunisia (Fodha and Zaghdoud 2010), for $\mathrm{CO}_{2}$ in China (Jalil and Mahmud 2009), Tunisia (Fodha and Zaghdoud 2010), Pakistan (Nasir and Rehman 2011), and Malaysia (Saboori, Sulaiman, and Mohd 2012). On the other hand, Vincent (1997) does not reach any conclusions about the EKC for any other kinds of air and water pollutants in Malaysia.

4 Bradford et al. (2005) note that this alternative specification is also valid if per capita income is a stationary variable.

5 The reduced form specification is only based on income. Panayotou (1997) underlines that "the EKC, in its reduced form, is a 'black box' that hides more than it reveals. We are left without any clue as to why the observed relationship exists and how to influence it. Without an explicit consideration of the underlying determinants of environmental quality, the scope for policy intervention is unduly circumscribed. Therefore, estimation of a reduced-form EKC should only be a first step in our effort to understand the environment-development relationship, not the endpoint." 
Table 1: Single country EKC studies: a review of the literature

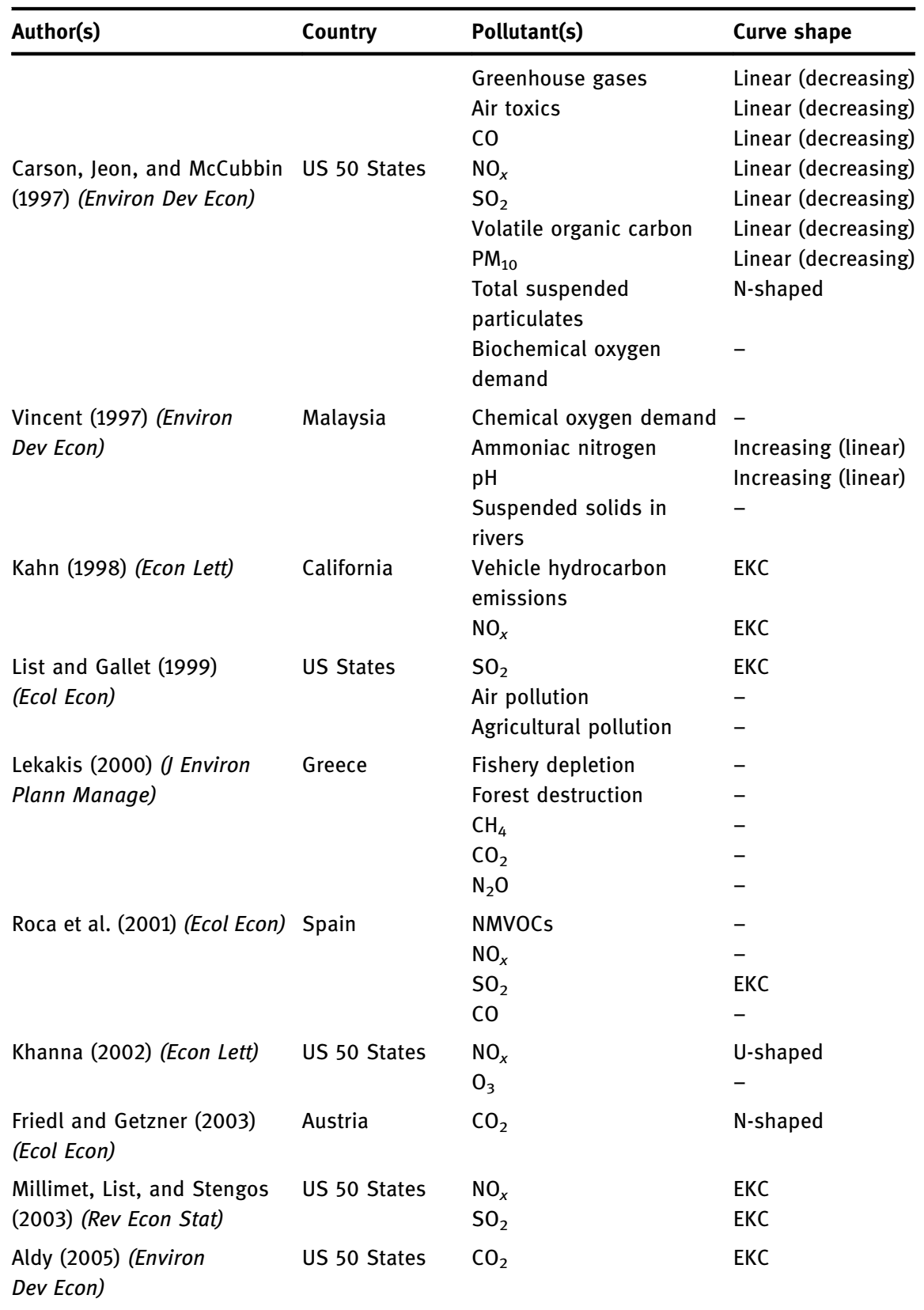

(continued) 
Table 1: (Continued)

\begin{tabular}{|c|c|c|c|}
\hline Author(s) & Country & Pollutant(s) & Curve shape \\
\hline Ang (2007) (Energy Pol) & France & $\mathrm{CO}_{2}$ & EKC \\
\hline $\begin{array}{l}\text { Cialani (2007) (Manage } \\
\text { Environ Qual Int J) }\end{array}$ & Italy & $\begin{array}{l}\mathrm{CO}_{2} \\
\mathrm{CH}_{4} \\
\mathrm{CO}\end{array}$ & $\begin{array}{l}\text { Linear (increasing) } \\
\text { EKC } \\
\text { EKC }\end{array}$ \\
\hline $\begin{array}{l}\text { Mazzanti, Montini, and } \\
\text { Zoboli (2008) Econ } \\
\text { Systems Res }\end{array}$ & $\begin{array}{l}\text { Italian } \\
\text { provinces }\end{array}$ & $\begin{array}{l}\mathrm{CO}_{2} \\
\mathrm{NO}_{x} \\
\mathrm{PM}_{10} \\
\mathrm{SO}_{x} \\
\mathrm{CO}_{2}\end{array}$ & $\begin{array}{l}\text { EKC } \\
- \\
- \\
- \\
\text { Linear (increasing) }\end{array}$ \\
\hline $\begin{array}{l}\text { Akbostancı, Türüt-Asik, and } \\
\text { Tunç (2009) (Energy Pol) }\end{array}$ & Turkey & $\begin{array}{l}\mathrm{PM}_{10} \\
\mathrm{SO}_{2}\end{array}$ & $\begin{array}{l}\mathrm{N} \text {-shaped } \\
\mathrm{N} \text {-shaped }\end{array}$ \\
\hline $\begin{array}{l}\text { Jalil and Mahmud (2009) } \\
\text { (Energy Pol) }\end{array}$ & China & $\mathrm{CO}_{2}$ & EKC \\
\hline $\begin{array}{l}\text { Fodha and Zaghdoud (2010) } \\
\text { (Energy Pol) }\end{array}$ & Tunisia & $\begin{array}{l}\mathrm{CO}_{2} \\
\mathrm{SO}_{2}\end{array}$ & $\begin{array}{l}\text { Linear (increasing) } \\
\text { EKC }\end{array}$ \\
\hline $\begin{array}{l}\text { He and Richard (2010) } \\
\text { (Ecol Econ) }\end{array}$ & Canada & $\mathrm{CO}_{2}$ & Linear (increasing) \\
\hline $\begin{array}{l}\text { Iwata, Okada, and Samreth } \\
\text { (2010) (Energy Pol) }\end{array}$ & France & $\mathrm{CO}_{2}$ & EKC \\
\hline $\begin{array}{l}\text { Nasir and Rehman (2011) } \\
\text { (Energy Pol) }\end{array}$ & Pakistan & $\mathrm{CO}_{2}$ & EKC \\
\hline $\begin{array}{l}\text { Park and Lee (2011) } \\
\text { (Energy Pol) }\end{array}$ & Korean regions & $\begin{array}{l}\mathrm{CO} \\
\mathrm{NO}_{x} \\
\mathrm{SO}_{2}\end{array}$ & $\begin{array}{l}\text { U-shaped } \\
- \\
-\end{array}$ \\
\hline $\begin{array}{l}\text { Fosten, Morley, and Taylor } \\
\text { (2012) (Ecol Econ) }\end{array}$ & United Kingdom & $\begin{array}{l}\mathrm{CO}_{2} \\
\mathrm{SO}_{2}\end{array}$ & $\begin{array}{l}\text { EKC } \\
\text { EKC }\end{array}$ \\
\hline $\begin{array}{l}\text { Saboori, Sulaiman, and } \\
\text { Mohd (2012) (Energy Pol) }\end{array}$ & Malaysia & $\mathrm{CO}_{2}$ & EKC \\
\hline
\end{tabular}

In fact, although the literature predicts that the relationship between economic growth and environmental degradation should be described by an inverse-Ushaped figure, this is not always confirmed by empirical evidence, calling into question the real existence of the EKC. ${ }^{6}$ Khanna (2002) extends Kahn's analysis, but the result is a U-shaped relationship instead of the inverted-U-shaped EKC. ${ }^{7}$

6 The debate about the robustness of the EKC hypothesis is formally analyzed by Stern (2004). 7 The various possible relationships between environmental stress and economic development which differ from the inverse-U-shaped figure are summarized for example by Dinda (2004, 440). 
Many other papers do not collect evidence of an EKC: for example a linear trend is observed for seven air pollutants in the 50 US States (Carson, Jeon, and McCubbin 1997) and for $\mathrm{CO}_{2}$ in Italy (Cialani 2007), Turkey (Akbostancı, TürütAsik, and Tunç 2009), and Canada (He and Richard 2010), while an N-shaped curve holds for $\mathrm{CO}_{2}$ in Austria (Friedl and Getzner 2003) and for $\mathrm{PM}_{10}$ and $\mathrm{SO}_{2}$ in Turkey (Akbostanc1, Türüt-Asik, and Tunç 2009). Mixed conclusions are reached by Mazzanti, Montini, and Zoboli (2008) and Park and Lee (2011) for many air pollutants in the Italian provinces and Korean regions respectively. No relationship is identified in Greece (Lekakis 2000).

\section{The model}

The relationship between measures of pollution and per capita income is traditionally estimated by means of the following equation (see, among others, Khanna 2002; Stern 2004; Ang 2007; and Orubu and Omotor 2011):

$$
p_{i t}=a_{i}+b y_{i t}+c y_{i t}^{2}+\varepsilon_{i t},
$$

where $i$ and $t$ refer to the $i$ th region and the year respectively. The variable $p_{i t}$ is the environmental stress, and $y_{i t}$ is the wealth indicator, generally represented by per capita GDP. The EKC is verified if the coefficients $b$ and $c$ in eq. [1] are positive $(b>0)$ and negative $(c<0)$ respectively. In fact, in this case, eq. [1] describes a quadratic inverse-U-shaped relationship between pollution and per capita income. For the reasons explained in Section 1, it is common practice in the literature to estimate eq. [1] in order to test the existence of the EKC. ${ }^{8}$ Furthermore, eq. [1] can be microfounded. To the best of our knowledge, one of the first attempts to microfound eq. [1] was made by Andreoni and Levinson (2001). The Appendix shows a specific version of their model, which gives precisely a microfoundation of eq. [1].

In particular, if the EKC exists, its turning point $\left(y_{i t}^{*}\right)$ is derived by maximizing eq. [1] with respect to $y_{i t}$, such as:

$$
\frac{\partial p_{i t}}{\partial y_{i t}}=b+2 c y_{i t}^{*}=0
$$

8 Moreover, eq. [1] is generally estimated with the inclusion of additional control variables with potentially explanatory power. For the sake of simplicity, the control variables used in our analysis are introduced at the end of this section. 
From eq. [2], we obtain that

$$
y_{i t}^{*}=-\frac{b}{2 c} .
$$

Then, we differentiate eq. [3] with respect to time in order to obtain

$$
\frac{\partial p_{i t}}{\partial t}=\left(b+2 c y_{i t}\right) \frac{\partial y_{i t}}{\partial t} .
$$

Finally, by substituting eq. [3] into eq. [4] and omitting the subscript $t$ for the sake of simplicity, we obtain the following condition:

$$
\frac{\partial p_{i}}{\partial t}=\alpha\left(y_{i}-y_{i}^{*}\right) g_{i}
$$

where the parameter $\alpha=2 c$ is negative since $c<0$ and $g_{i}=\frac{\partial y_{i}}{\partial t}$ is the income growth rate in each region. Eq. [5] suggests that the instantaneous change of pollution depends on the income growth rate $g_{i}$ and on the distance of income $y_{i}$ to its turning point $y_{i}{ }^{*}$. It is also easy to see that eq. [5] corresponds to the new specification of the EKC proposed by Bradford et al. (2005), in order to best describe the long-term interaction between pollution and wealth. If the EKC is verified and $g_{i}>0$, pollution increases when $y_{i}<y_{i}{ }^{*}$ while the trend reverses when $y_{i}>y_{i}{ }^{*}$.

In the literature, different papers demonstrate that technological progress is the theoretical fundamental of the EKC. Andreoni and Levinson (2001) find that the inverse-U-shaped relationship between pollution and per capita income directly depends on the technology of production and abatement. Chimeli and Braden (2005) show that differences in TFPs imply different income levels across countries with important consequences in terms of the environment. Brock and Taylor (2010) find that the EKC is the result of the convergence to a sustainable growth path when technological progress in abatement is introduced into the Solow model. If growth is sustainable, the EKC turning point is reached at a lower level of capital per effective worker than the one for the steady state. ${ }^{9}$ Although in a quite different context, Chimeli (2007) shows that the transition time at which environmental quality starts to improve depends on three main aspects of technological progress such as heterogeneous TFPs, efficiency of expenditure on environmental protection, and pollution intensity of capital. These three parameters are sources of heterogeneity across economies in determining how lengthy their transition time will be.

9 Note that the EKC turning point does not coincide with the steady state of the "Green Solow Model". 
In the light of the general widespread consensus about the importance of technology in the relationship between environmental quality and economic growth and given that, if the EKC exists, different aspects of innovation affect both the distance and the speed with which an economy moves toward the turning point (Chimeli 2007), in this paper we extend the Bradford et al. (2005) model in order to capture the impact of innovation on the EKC and on its turning point as follows ${ }^{10}$ :

$$
y_{i}^{*}=\lambda_{0}+\lambda_{1} T_{i}+\lambda_{2} T_{i}^{2}+\lambda_{3} T_{i}^{3} .
$$

The variable $T_{i}$ is the average innovation level over the sample period in each region and is proposed as a proxy for the different types of technological progress that might affect $y_{i}^{*},{ }^{11}$ and $\lambda_{0}$ is a generic constant. Eq. [6] formalizes a generic cubic linkage between technological progress (and income) and pollution. Since to the best of our knowledge in the theoretical literature there is no a general conclusion about how technology influences the turning point of the EKC, we do not impose a priori any assumptions about the signs of the coefficients of interest, $\lambda_{0}, \lambda_{1}, \lambda_{2}$, and $\lambda_{3}$. This is a question to be addressed empirically. Moreover, eq. [6] allows computation of the EKC considering explicitly those region-specific characteristics generally neglected in the empirical literature, since neither fixed nor random effects can entirely capture them (See also Chimeli and Braden 2005).

We substitute eq. [6] into eq. [5], in order to get

$$
\frac{\partial p_{i}}{\partial t}=\alpha\left[y_{i}-\left(\lambda_{0}+\lambda_{1} T_{i}+\lambda_{2} T_{i}^{2}+\lambda_{3} T_{i}^{3}\right)\right] g_{i}
$$

We then integrate eq. [7] with respect to time, where $y_{i}$ and $g_{i}$ are assumed to be constant in time. ${ }^{12}$ We obtain that

$$
p_{i}=\mu+\alpha\left[y-\left(\lambda_{0}+\lambda_{1} T_{i}+\lambda_{2} T_{i}^{2}+\lambda_{3} T_{i}^{3}\right)\right] g_{i} t,
$$

10 A similar procedure is proposed by Leitão (2010), who tests the existence of a positive linear correlation between corruption and the turning point of the EKC.

11 For example, in the theoretical model proposed by Chimeli (2007), the three types of innovation have different impacts on the transition time. A negative effect is found for pollution intensity of capital, a single-peaked relationship for the case of efficiency of expenditures on environmental protection, and an ambiguous conclusion is reached for TFP.

12 They are therefore the average income level and the average income growth rate in each region. 
where $\mu$ is a constant of integration. The equation to be estimated is obtained (including again the subscript $t$ ) by adding to eq. [8] the control variables $Z_{i t}$ and the error term $\epsilon_{i t}$. So we get

$$
p_{i t}=\mu_{i}+\beta_{0}\left(y_{i} g_{i} t\right)+\beta_{1}\left(g_{i} t\right)+\beta_{2}\left(T_{i} g_{i} t\right)+\beta_{3}\left(T_{i}^{2} g_{i} t\right)+\beta_{4}\left(T_{i}^{3} g_{i} t\right)+\beta_{5} Z_{i t}+\epsilon_{i t} .
$$

In this paper, we estimate the new specification of the EKC introduced by eq. [9] for three different pollutants per euro of GDP $\left(p_{i t}\right)$ : carbon monoxide emissions $\left(\mathrm{CO}_{i t}\right)$, non-methane volatile organic compounds $\left(\mathrm{NMVOCS}_{i t}\right)$, and sulfur oxides $\left(S O X_{i t}\right)$. As in Bradford et al. (2005), the EKC is verified if $\alpha<0$, so if $\beta_{0}<0$, given that $\alpha=\beta_{0}$. Similar to Leitão (2010), this new specification of the EKC does not allow estimation of the turning point $y_{i}^{*}$. Note also that the sign of the coefficients $\beta_{1}=-\alpha \lambda_{0}, \beta_{2}=-\alpha \lambda_{1}, \beta_{3}=-\alpha \lambda_{2}$, and $\beta_{4}=-\alpha \lambda_{3}$ in turn depends on the sign of the parameters $\lambda_{0}, \lambda_{1}, \lambda_{2}$, and $\lambda_{3}$ respectively, which are not a priori determined. They can however be indirectly verified since $\lambda_{0}=-\frac{\beta_{1}}{\alpha}, \lambda_{1}=-\frac{\beta_{2}}{\alpha}$, $\lambda_{2}=-\frac{\beta_{3}}{\alpha}$, and $\lambda_{3}=-\frac{\beta_{4}}{\alpha}$.

Consider, for example, the case where innovation linearly influences the turning point of the EKC. In this situation, we expect a negative correlation between the turning point of the EKC and technological progress, i.e. the more innovative a country (region), the lower the level of the turning point of the EKC where pollution begins to decrease. Given that $\alpha<0$, the parameter $\lambda_{1}$ is negative $\left(\lambda_{1}<0\right)$ and consequently $\beta_{2}$ is also negative $\left(\beta_{2}<0\right)$, while the coefficients $\beta_{3}$ and $\beta_{4}$ are both equal to zero $\left(\beta_{3}=\beta_{4}=0\right)$ since $\lambda_{2}$ and $\lambda_{3}$ are equal to zero $\left(\lambda_{2}=\lambda_{3}=0\right)$. Although, as noted above, the theoretical literature recognizes the central role of technological progress in the relationship between economic growth and the environment, it does not give any clear indications about how innovation impacts on pollution (see Chimeli 2007 and Smulders, Bretschger, and Egli 2011). Therefore, this is only one of the possible outcomes, since data can support either quadratic or cubic specification of eq. [6].

Finally, $Z_{i t}$ is a set of control variables widely used in the literature, including for example the literacy rate (see, for example Gangadharan and Valenzuela 2001 and Orubu and Omotor 2011) and some measures of trade and structural change introduced by Suri and Chapman (1998). See the following section for a more detail description of these control variables.

As in Leitão (2010) we proceed in two phases. Technological progress is expected to influence not only the turning point of the EKC as hypothesized by eq. [6] but also the country's level of income and its growth. There is in fact a widespread consensus in the literature about the positive influence of technology on economic growth (see, among others, Islam 1995; Caselli, Esquivel, and 
Lefort 1996; and Dowrick and Rogers 2002). Moreover, this is in line with the most recent European policies, whose goal is to optimize support for research, development, and innovation in order to foster competitiveness and growth, with special attention to climate change and the environment (European Commission 2010a, 2010b). ${ }^{13}$ In the specific case of the Italian regions, Bianchi and Menegatti (2008) demonstrate that promotion of technological transfers and increasing R\&D expenditures are fundamental for income convergence across regions. Furthermore, it is well-known in the literature that there is significant technological heterogeneity across the 20 regions of Italy (Leonida, Petraglia, and Murillo-Zamorano 2004; Bianchi and Menegatti 2008; Mazzanti, Montini, and Zoboli 2008; and Ghisetti and Quartraro 2013). Consequently, neglecting the close linkage between income and these territorial specific effects typically related to innovation may produce misleading results. For these reasons, eq. [10] is first of all estimated in order to capture the positive influence of technology on economic activity without ignoring differences across regions:

$$
Y_{i t}=\omega_{i}+\delta_{1} T_{i t}+\delta_{2} S_{i t}+\delta_{3} W_{i t}+\xi_{i t}
$$

Per capita income $Y_{i t}$ is expressed as a function of technological progress $\left(T_{i t}\right)$, which, following Komen, Gerking, and Folmer (1997) and Dinda (2004), is proxied with regional expenditure on R\&D in the years 1990-2005. We instrument $T_{i t}$ with other proxies of technological progress, such as per capita patents $\left(P A T_{i t}\right)$ and energy intensity in the industry $\left(E N G_{i t}\right)$. Per capita gross investment $S_{i t}$ is used as a proxy of capital accumulation. As in Leitão (2010) a set of control variables $\left(W_{i t}\right)$, widely used in the growth literature, is introduced into eq. [10]. These are population $\left(P O P_{i t}\right)$, the share of trade in the region's GDP (TRADE $\left.i t\right)$, and life expectancy at birth $\left(L I F E_{i t}\right)$, used as a proxy of health. $\omega_{i}$ is the unobserved region-specific effect, and $\xi_{i t}$ is the error term. A positive effect of innovation on GDP is verified if $\delta_{1}>0$. We then estimate eq. [9] using fitted values of per capita income previously obtained from eq. [10].

13 In particular, innovation is one of the main pillars of the new CAP (Common Agricultural Policy) toward 2020, not only because it favors competitiveness and growth but also for the great potential of the agricultural sector to mitigate, adapt, and make a positive contribution to environmental protection through greenhouse gas emissions reduction and production efficiency measures, including improvements in energy efficiency (European Commission 2010b). 


\section{The data}

The EKC hypothesis is checked for three different air pollutants: CO, NMVOCs, and $\mathrm{SO}_{x}$. Emission levels are expressed as metric tons. These data are available at regional level on the ISPRA (Italian Institute for Environmental Protection and Research) website (February 2010) for the years 1990, 1995, 2000, and $2005 .^{14}$ We calculate emission levels per euro of GDP for each pollutant as the dependent variable in the functional form [9]. Variables $y_{i}$ and $g_{i}$ are calculated following Bradford et al. (2005). ${ }^{15}$ In eq. [9], $T_{i}$ is the average degree of innovative spending in the $i$ th region. Per capita income and technological progress data are downloaded from Eurostat Regional Statistics.

We estimate eq. [9] considering different control variables such as $E D U_{i t}$, the Gross Percentage of Secondary School Enrollment retrieved from the ISTAT Territorial Indicator database. The school-enrollment rate is a good proxy of human capital and is used both in economic growth literature (Caselli, Esquivel, and Lefort 1996 and Dowrick and Rogers 2002) and in EKC studies (see for example Gangadharan and Valenzuela 2001 and Orubu and Omotor 2011). We extend this basic model in order to test the significance of international trade, given that trade plays a crucial role in the EKC literature, as well as in the Italian economy. In fact, international trade is one of the most important factors in explaining the downward sloping portion of the EKC. This is principally due to "the pollution heaven hypothesis", i.e. the transformation of advanced economies that "cease to produce certain pollution intensive goods and begin instead to import these from other countries with less restrictive environmental protection laws” (Grossman and Krueger 1995).

In many papers the openness of a country is measured as the sum of total exports and imports divided by GDP. Suri and Chapman (1998) point out that this is a poor way of defining trade, because it does not capture the impact of differential competition between imports and exports. Following them, we introduce two explanatory variables which better capture the effect of cross-country movements of polluting goods, defined as $X_{i t}$ and $M_{i t} . X_{i t}$ and $M_{i t}$ are the share of manufacturing good exports and imports in manufacturing value added; their expected signs are positive and negative respectively. All trade data are freely available on the database Coeweb, supplied by ISTAT. Finally, as in Suri and

14 Emissions data at regional level for more recent years are not currently available.

15 We indicate as $Y_{i}^{1}$ the average per capita income in region $i$ over the period 1990-1993 and as $Y_{i}^{2}$ the average over the period 2002-2005. The average growth rate $g_{i}$ is derived from this condition $Y_{i}^{2}=Y_{i}^{1} \exp \left(12 g_{i}\right)$, while $y_{i}=Y_{i}^{1} \exp \left(6 g_{i}\right)$ is the interpolated income at in the sample mid-point. 
Chapman, we also consider a measure of structural transformation of the economy, $M F G_{i t}$, computed as the ratio between manufacturing value added and total regional GDP. Its expected sign is positive.

Per capita income used to test the existence of the EKC in Italian regions is obtained from eq. [10]. In this case, the control variables are the ratio of gross investment on GDP $\left(S_{i t}\right)$, the population level $\left(P O P_{i t}\right)$, the ratio between the sum of total export and import and GDP (TRADE $\left.E_{i t}\right)$, and finally, life expectancy at

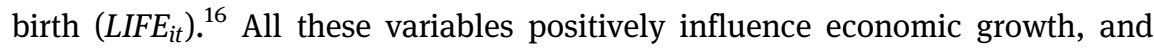
they are added incrementally into the equation.

Descriptive statistics of the data for eqs [9] and [10] are reported separately in Tables 2 and 3 respectively. ${ }^{17}$ In particular, the correlation matrix among the variables used in the regressions suggests the positive relationship between $T_{i t}$ and $Y_{i t} . Y_{i t}$ is also positively correlated with $E D U_{i t}, M F G_{i t}, P A T_{i t}, S_{i t}$, and the variables related to trade $\left(X_{i t}, M_{i t}\right.$, and TRADE $\left.E_{i t}\right)$. Moreover, $Y_{i t}$ is negatively correlated with the three pollutants considered and $E N G_{i t}{ }^{18}$ This evidence thus supports the idea of an inverse relationship between growth and environmental

Table 2: Descriptive statistics of the variables in eq. [9]

\begin{tabular}{lrrrrrrrrr}
\hline & CO $_{\text {it }}$ & EDU $_{\text {it }}$ & $\boldsymbol{M}_{\text {it }}$ & MFG $_{\text {it }}$ & NMVOCS $_{\text {it }}$ & SOX $_{\text {it }}$ & $\boldsymbol{T}_{\text {it }}$ & $\boldsymbol{X}_{\text {it }}$ & $\boldsymbol{Y}_{\text {it }}$ \\
\hline Mean & 0.62 & 4.48 & 3.78 & 3.23 & -1.59 & -2.88 & -0.30 & 3.91 & 9.87 \\
Std. Dev. & 0.74 & 0.09 & 0.79 & 0.50 & 0.53 & 1.23 & 0.56 & 0.81 & 0.36 \\
Obs & 80 & 220 & 300 & 320 & 80 & 80 & 220 & 300 & 320 \\
\multicolumn{1}{l}{ Correlation matrix } & & & & & & & & \\
CO $_{i t}$ & 1 & & & & & & & & \\
EDU $_{i t}$ & -0.34 & 1 & & & & & & & \\
$M_{i t}$ & -0.33 & -0.10 & 1 & & & & & & \\
MFG $_{i t}$ & -0.21 & -0.35 & 0.26 & 1 & & & & & \\
NMVOCS & 0.83 & -0.37 & -0.43 & -0.17 & 1 & & & & \\
SOX $_{i t}$ & 0.59 & -0.16 & 0.10 & -0.14 & 0.57 & 1 & & & \\
$T_{i t}$ & -0.11 & 0.28 & 0.51 & -0.07 & -0.33 & 0.02 & 1 & & \\
$X_{i t}$ & -0.41 & 0.00 & 0.71 & 0.65 & -0.41 & 0.03 & 0.38 & 1 & \\
$Y_{i t}$ & -0.76 & 0.04 & 0.59 & 0.62 & -0.72 & -0.37 & 0.20 & 0.68 & 1 \\
\hline
\end{tabular}

Note: All the variables are in log.

16 Leitão (2010) follows a similar approach.

17 Note that all the variables are log transformed.

18 Energy consumption is sometimes used in the literature as a proxy of pollution. See, for example, Suri and Chapman (1998). 
Table 3: Descriptive statistics of the variables in eq. [10]

\begin{tabular}{lrrrrrrrr}
\hline & ENG $_{\text {it }}$ & LIFE $_{\text {it }}$ & PAT $_{\text {it }}$ & POP $_{\text {it }}$ & $\boldsymbol{S}_{\text {it }}$ & $\boldsymbol{T}_{\text {it }}$ & TRADE $_{\text {it }}$ & $\boldsymbol{Y}_{\text {it }}$ \\
\hline Mean & 4.95 & 4.16 & 3.18 & 14.44 & 3.05 & -0.30 & 3.14 & 9.87 \\
Std. Dev. & 0.50 & 0.92 & 1.34 & 1.05 & 0.16 & 0.56 & 0.71 & 0.36 \\
Obs & 320 & 320 & 320 & 320 & 220 & 220 & 320 & 320 \\
\multicolumn{2}{l}{ Correlation matrix } & & & & & & & \\
ENG $_{\text {it }}$ & 1 & & & & & & & \\
LIFE $_{\text {it }}$ & 0.13 & 1 & & & & & & \\
PAT $_{\text {it }}$ & -0.23 & -0.21 & 1 & & & & & \\
POP $_{i t}$ & -0.10 & -0.19 & 0.23 & 1 & & & & \\
$S_{i t}$ & 0.15 & -0.01 & -0.22 & -0.53 & 1 & & & \\
$T_{i t}$ & -0.04 & 0.12 & 0.53 & 0.58 & -0.45 & 1 & & \\
TRADE $_{\text {it }}$ & 0.05 & -0.25 & 0.78 & 0.26 & -0.23 & 0.53 & 1 & \\
$Y_{\text {it }}$ & -0.31 & -0.11 & 0.76 & -0.08 & 0.12 & 0.20 & 0.55 & 1 \\
\hline
\end{tabular}

Note: See Table 2.

stress. A negative correlation between the three pollutants and $E D U_{i t}$ is also observed. Finally, the data in Table 3 show a clear relationship (a negative and positive correlation) between $T_{i t}$ and the variables chosen as its instruments, $E N G_{i t}$ and $P A T_{i t}$.

\section{Econometric results}

In this section, we present the results obtained from estimations of eqs [9] and [10]. The equations are estimated with the inclusion of both fixed and random effects as in Bradford et al. (2005) and Leitão (2010). To save space, random effects estimations are not reported in the tables. They are available on request from the author.

Table 4 shows the estimates of eq. [10]. Real per capita income is a function of innovation and the ratio of gross investment on GDP ( $T_{i t}$ and $S_{i t}$ respectively) in Model (a). Models (b)-(d) add population $\left(P O P_{i t}\right)$, the ratio of international trade on GDP (TRADE $E_{i t}$ ), and life expectancy at birth $\left(L I F E_{i t}\right)$. The variable $T_{i t}$ is instrumented using the Two-Stage Least Squares estimator. The hypothesis $\delta_{1}>0$ is always verified since this coefficient is positive and highly statistically significant in all the models in Table 4. The same conclusion is found for $S_{i t}$, TRADE $E_{i t}$, and $L I F E_{i t}$, while the opposite holds for the case of $P O P_{i t}$. The Anderson canonical correlations test indicates that the model is identified in all the cases. Sargan's test does not reject the null hypothesis at the conventional critical value, so the 
Table 4: Estimation results of eq. [10] - fixed effects

\begin{tabular}{|c|c|c|c|c|}
\hline Dependent variable: $Y_{i t}$ & (a) & (b) & (c) & (d) \\
\hline$T_{i t}$ & $\begin{array}{c}0.32 \\
(0.07)^{\star \star \star}\end{array}$ & $\begin{array}{c}0.31 \\
(0.08)^{\star \star \star}\end{array}$ & $\begin{array}{c}0.25 \\
(0.08)^{\star \star \star}\end{array}$ & $\begin{array}{c}0.21 \\
(0.07)^{\star \star \star \star}\end{array}$ \\
\hline$S_{i t}$ & $\begin{array}{c}0.91 \\
(0.14)^{\star \star \star}\end{array}$ & $\begin{array}{c}0.89 \\
(0.14)^{\star \star \star}\end{array}$ & $\begin{array}{l}0.80 \\
(0.12)^{\star \star \star}\end{array}$ & $\begin{array}{l}0.60 \\
(0.11)^{\star \star \star \star}\end{array}$ \\
\hline$P O P_{i t}$ & - & $\begin{array}{r}0.63 \\
(0.56)\end{array}$ & $\begin{array}{c}0.91 \\
(0.53)^{\star}\end{array}$ & $\begin{array}{l}-0.29 \\
(0.49)\end{array}$ \\
\hline$T R A D E_{i t}$ & - & - & $\begin{array}{c}0.25 \\
(0.06)^{\star \star \star}\end{array}$ & $\begin{array}{c}0.19 \\
(0.06)^{\star \star \star}\end{array}$ \\
\hline $\operatorname{LIFE}_{i t}$ & - & - & - & $\begin{array}{c}2.37 \\
(0.34)^{\star \star \star \star}\end{array}$ \\
\hline$R^{2}$ & 0.41 & 0.42 & 0.52 & 0.64 \\
\hline Anderson canonical correlations LM statistic & 41.21 & 38.45 & 34.53 & 34.29 \\
\hline$p$-value & 0.00 & 0.00 & 0.00 & 0.00 \\
\hline Cragg-Donald Wald $F$ statistic & 25.57 & 23.32 & 20.35 & 20.08 \\
\hline First stage $F$ statistic & 27.22 & 20.61 & 21.37 & 17.72 \\
\hline$p$-value & 0.00 & 0.00 & 0.00 & 0.00 \\
\hline Anderson-Rubin Wald test $\left(\chi^{2}\right)$ & 24.24 & 22.39 & 15.48 & 12.99 \\
\hline$p$-value & 0.00 & 0.00 & 0.00 & 0.00 \\
\hline Stock-Wright LM $S$ statistic $\left(\chi^{2}\right)$ & 21.62 & 20.14 & 14.36 & 12.20 \\
\hline$p$-value & 0.00 & 0.00 & 0.00 & 0.00 \\
\hline Sargan's statistic & 2.10 & 3.17 & 2.37 & 1.55 \\
\hline$p$-value & 0.15 & 0.07 & 0.12 & 0.21 \\
\hline Endogeneity test & 7.29 & 6.35 & 6.68 & 5.53 \\
\hline$p$-value & 0.01 & 0.01 & 0.01 & 0.01 \\
\hline Hausman's test & 0.52 & 1.87 & 13.76 & 18.70 \\
\hline$p$-value & 0.77 & 0.60 & 0.01 & 0.00 \\
\hline
\end{tabular}

Notes: All the variables are in log; Asymptotic standard errors are reported in brackets; *, **, and *** indicate significance at 10,5 , and $1 \%$ levels; $T_{i t}$ is instrumented with $E N G_{i t}$ and $P A T_{i t}$; The Anderson canonical correlations test is a likelihood-ratio test of whether the equation is identified. Under the null of underidentification, the statistic is distributed as $\chi^{2}$ with degrees of freedom equal to $L-R+1$ where $L$ and $R$ are the number of instruments and regressors respectively. A rejection of the null indicates that the model is identified; The Cragg-Donald statistic is a test for weak identification, which arises when the excluded instruments are weakly correlated with the endogenous regressors. Critical values for single endogenous regressor are provided by Stock and Yogo (2005) as follows: 10, 15, 20 , and $25 \%$ maximal IV sizes are $19.93,11.59,8.75$, and 7.25 respectively; Weak-instrument-robust inference is verified by the Anderson-Rubin Wald test and by the Stock-Wright LM $S$ statistic. The null hypothesis of these two tests is the joint significance of endogenous regressors and the validity of the overidentifying restrictions. Both statistics are distributed as $\chi^{2}$ with degrees of freedom equal to the number of excluded instruments; Sargan's test is a test of overidentifying restrictions. The joint null hypothesis is that the instruments are valid instruments; The endogeneity test (or "GMM distance" or "difference-in-Sargan" statistic) is a test of the exogeneity of one or more instruments. The null hypothesis is that an endogenous variable can be treated as exogenous; Finally, Hausman's test is based on estimating the variance of the difference of the fixed and random effects estimators and it is distributed as $\chi^{2}$ with degrees of freedom equal to the number of regressors. 
instruments chosen are proven to be statistically valid. Furthermore, the first stage $F$ statistic indicates the exclusion of "weak" instruments ${ }^{19}$; the Cragg-Donald statistic, the Anderson-Rubin Wald test, and the Stock-Wright LM $S$ statistic formally confirm this finding. We also performed a test on the endogeneity of $T_{i t}$. Finally, Hausman's test indicates that fixed effects are the appropriate specification in Models (c) and (d), while random effects are preferred in Models (a) and (b). Bradford et al. (2005) and Leitão (2010) state that fixed effects may be more appropriate than random effects, because they capture the correlation between specific unobserved effects and the explanatory variables. Furthermore, regional unobserved characteristics are correlated with income. Given this fact and the higher value of $R^{2}$, we choose Model (d) to fit per capita GDP. Fitted values of per capita income are then used in eq. [9]. ${ }^{20}$

Table 5 reports the estimation results of eq. [9] for $C O_{i t}, N M V O C S_{i t}$, and $S O X_{i t}$ (Panels A-C respectively) with the inclusion of fixed effects. ${ }^{21}$ For all the pollutants, a basic model is estimated adding the school-enrollment rate $\left(E D U_{i t}\right)$ as control variable (Column 1). $E D U_{i t}$ is highly significant and shows the expected negative sign. Columns (2) to (4) also consider the share of manufacturing good exports and imports in manufacturing value added ( $X_{i t}$ and, $M_{i t}$ respectively) and finally the ratio between manufacturing value added and total regional GDP $\left(M F G_{i t}\right)$. With regard to $X_{i t}$, the estimated sign is always positive but it is significant only in Columns (3) and (4) for the case of NMVOCS $S_{i t} M_{i t}$ presents the sign predicted by the literature (see Suri and Chapman 1998) and is significant for $\mathrm{CO}_{i t}$ and $N M V O C S_{i t}$. Finally, $M F G_{i t}$ does not show the expected sign, and it is not statistically different from zero at the conventional critical value. ${ }^{22}$ Similar to Bradford et al. (2005), coefficient $\beta_{1}$ is positive and highly significant in Panels (A) and (B) of Table 5. In line with Bradford et al. (2005) and Leitão

19 The instruments are "weak" if the first stage $F$ statistic is less than 10 . See also Wooldridge (2002, Chapter 5).

20 In order to save space, descriptive statistics of fitted values of per capita income from eq. [10], Model (d), and some popular panel unit-root tests are available on request from the author.

$21 R \& D$ data at regional level are not available for the years 1990-1994. For this reason, fitted values of per capita income are missing for these years. In order to compute $y_{i}$ and $g_{i}$ according to the indications of Bradford et al. (2005) summarized in Section 4, we compute the mean estimated errors $\bar{\zeta}_{i}$ as the mean of the difference between fitted and observed per capita income as follows: $\bar{\zeta}_{i}=\frac{1}{10} \sum\left(\hat{y}_{i t}-y_{i t}\right)$ for all $i=1, \ldots, 20$ and for all $t=1995, \ldots, 2005$. We can thus replace the missing observations for the years 1990-1994 according to the following equation: $\hat{y}_{i t}=y_{i t}+\bar{\zeta}_{i}$ for all $i=1, \ldots, 20$ and $t=1990, \ldots, 1994$. Finally, in order to compute $T_{i}$, we note that $R \& D$ does not substantially vary for each region over time. For this reason, $T_{i}$ is simply computed considering the data available.

22 A similar result is also found by Iwata, Okada, and Samreth (2012). 
Table 5: Estimation results of eq. [9] for $\mathrm{CO}_{i t}$ (Panel A), NMVOCS $_{i t}$ (Panel B), and SOX (Panel C) - fixed effects

(1)

(2)

(3)

(4)

\section{Panel (A)}

$y_{i} g_{i} t$

$g_{i} t$

$T_{i} g_{i} t$

$T_{i}^{2} g_{i} t$

$T_{i}^{3} g_{i} t$

$E D U_{i t}$

$X_{i t}$

$M_{i t}$

$M F G_{i t}$

$R^{2}$

Hausman's test

$p$-value

\section{Panel (B)}

$y_{i} g_{i} t$

$g_{i} t$

$T_{i} g_{i} t$

$T_{i}^{2} g_{i} t$

$T_{i}^{3} g_{i} t$

$E D U_{i t}$

$X_{i t}$

$M_{i t}$

$M F G_{i t}$ $-1.16^{\star \star \star}$

(0.35)

$10.44^{\star \star *}$

(3.61)

0.94

21.27

0.00

$-1.17^{\star \star \star}$
$(0.36)$
$10.59^{\star \star \star}$
$(3.70)$
$-0.89^{\star \star \star}$
$(0.31)$

0.21

$(0.60)$

$-0.16$

(0.21)

$-4.24^{\star \star \star}$

(0.76)

0.05

(0.17)

-$$
-
$$

0.94

26.79

0.00

$$
\begin{aligned}
& -0.83^{\text {** }}(0.31) \\
& 7.54^{* \star}
\end{aligned}
$$$$
7.54^{\text {** }}
$$

(3.19)

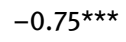

(0.27)

0.25

(0.52)

$-0.26$

(0.18)

$-3.68^{\star \star *}$

(0.62)

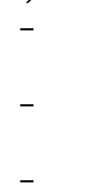

$(0.28)$

0.28

$-1.21^{\star \star \star}$
$(0.34)$
$11.06^{\star \star \star}$
$(3.56)$
$-0.91^{\star \star \star}$
$(0.30)$

$-1.22^{\star \star \star}$

(0.35)

$11.21^{\star \star \star}$

(3.66)

$-0.98^{\star \star}$

(0.41)

$0.22 \quad 0.24$

$(0.57)$

(0.58)

$-0.24$

$-0.27$

(0.20)

(0.24)

$-3.94^{\star \star \star}$

$-3.97^{\star \star \star}$

(0.74)

(0.76)

0.31

0.31

(0.21)

$(0.22)$

$-0.43^{\star}$

$-0.47^{\star}$

(0.22)

$(0.27)$

$-0.18$

(0.67)

0.95

0.95

25.90

26.40

0.00

0.00

$-0.93^{\star \star \star}$

(0.30)

$(0.30)$

8.70 ***

(3.07)

(3.14)

$-0.75^{\star \star \star}$

$-0.92^{\star \star}$

$(0.26)$

(0.35)

0.30

0.33

(0.49)

(0.50)

-0.32 *

$(0.18)$

$-0.40^{*}$

$(0.21)$

$-3.55^{\star \star \star}$

$-3.62^{\star \star \star}$

(0.64)

$(0.65)$

$0.36^{*}$

(0.18)

$0.36^{*}$

(0.18)

$-0.42^{\star \star}$

(0.19)

$-0.51^{\star \star}$

(0.23)

$-0.42$

(0.58) 
Table 5: (Continued)

\begin{tabular}{|c|c|c|c|c|}
\hline & (1) & (2) & (3) & (4) \\
\hline$R^{2}$ & 0.92 & 0.93 & 0.94 & 0.94 \\
\hline Hausman's test & 25.82 & 26.14 & 24.60 & 22.82 \\
\hline$p$-value & 0.00 & 0.00 & 0.00 & 0.00 \\
\hline \multicolumn{5}{|l|}{ Panel (C) } \\
\hline$y_{i} g_{i} t$ & $\begin{array}{l}-1.49^{\star} \\
(0.81)\end{array}$ & $\begin{array}{l}-1.54^{\star} \\
(0.83)\end{array}$ & $\begin{array}{l}-1.60^{\star} \\
(0.82)\end{array}$ & $\begin{array}{l}-1.69^{\star} \\
(0.84)\end{array}$ \\
\hline$g_{i} t$ & $\begin{array}{r}12.74 \\
(8.44)\end{array}$ & $\begin{array}{r}13.25 \\
(8.64)\end{array}$ & $\begin{array}{r}14.11 \\
(8.49)\end{array}$ & $\begin{array}{l}14.95^{\star} \\
(8.69)\end{array}$ \\
\hline$T_{i} g_{i} t$ & $\begin{array}{l}-1.55^{\star \star} \\
(0.72)\end{array}$ & $\begin{array}{l}-1.53^{\star \star} \\
(0.73)\end{array}$ & $\begin{array}{l}-1.56^{\star \star} \\
(0.72)\end{array}$ & $\begin{array}{l}-1.94^{*} \\
(0.97)\end{array}$ \\
\hline$T_{i}^{2} g_{i} t$ & $\begin{array}{r}1.20 \\
(1.37)\end{array}$ & $\begin{array}{r}1.25 \\
(1.39)\end{array}$ & $\begin{array}{r}1.28 \\
(1.37)\end{array}$ & $\begin{array}{r}1.35 \\
(1.39)\end{array}$ \\
\hline$T_{i}^{3} g_{i} t$ & $\begin{array}{r}0.06 \\
(0.48)\end{array}$ & $\begin{array}{r}0.07 \\
(0.49)\end{array}$ & $\begin{array}{l}-0.07 \\
(0.49)\end{array}$ & $\begin{array}{l}-0.25 \\
(0.58)\end{array}$ \\
\hline$E D U_{i t}$ & $\begin{array}{l}-5.12^{\star \star \star} \\
(1.65)\end{array}$ & $\begin{array}{l}-5.36^{\star \star \star} \\
(1.76)\end{array}$ & $\begin{array}{l}-4.80^{\star \star} \\
(1.77)\end{array}$ & $\begin{array}{l}-4.97^{\star \star \star} \\
(1.81)\end{array}$ \\
\hline$X_{i t}$ & - & $\begin{array}{r}0.17 \\
(0.40)\end{array}$ & $\begin{array}{r}0.65 \\
(0.51)\end{array}$ & $\begin{array}{r}0.65 \\
(0.51)\end{array}$ \\
\hline$M_{i t}$ & - & - & $\begin{array}{l}-0.80 \\
(0.53)\end{array}$ & $\begin{array}{r}-1.01 \\
(0.64)\end{array}$ \\
\hline$M F G_{i t}$ & - & - & - & $\begin{array}{l}-0.95 \\
(1.60)\end{array}$ \\
\hline$R^{2}$ & 0.84 & 0.84 & 0.85 & 0.85 \\
\hline Hausman's test & 18.41 & 17.88 & 22.58 & 23.17 \\
\hline$p$-value & 0.00 & 0.01 & 0.00 & 0.00 \\
\hline
\end{tabular}

Notes: Panels (A)-(C) refer to the estimates obtained when $\mathrm{CO}$, NMVOCs, and $\mathrm{SO}_{x}$ are considered as dependent variables respectively; Asymptotic standard errors are reported in parentheses; ${ }^{\star}$, **, and ${ }^{\star \star \star}$ indicate significance at 10,5 , and $1 \%$ levels; $y_{i} g_{i} t, g_{i} t, T_{i} g_{i} t, T_{i}^{2} g_{i} t$, and $T_{i}^{3} g_{i} t$ are computed considering the log transformation of $Y_{i t}$ and $T_{i t}$; All the other variables are in log.

(2010), Hausman's test always rejects the null hypothesis in favor of fixed effects. Furthermore, the inclusion of region-specific characteristics probably correlated with income, such as technological progress, ensures unbiased and consistent estimates.

Table 5 provides two different results. First of all, the hypothesis of an inverseU-shaped relationship between per capita income and environmental degradation is verified for the three pollutants; coefficient $\beta_{0}$ is negative and significant in all the estimates as Bradford et al. (2005) indicate. As far as we know, EKC studies for Italy are rare; Cialani (2007) only investigates this framework for $\mathrm{CO}_{2}$ using a time series approach, but her results indicate an increasing linear relationship between 
the pollutant and per capita income. Mixed results are also found by Mazzanti, Montini, and Zoboli (2008). To the best of our knowledge, this is the first time that the EKC has been studied in the 20 regions of Italy for CO, NMVOCs, and $\mathrm{SO}_{x}$. In general, in the single country EKC literature, heterogeneous results for $\mathrm{CO}$ are obtained by Carson, Jeon, and McCubbin (1997) and Khanna (2002) in the USA and by Park and Lee (2011) for the Korean regions, while Roca et al. (2001) do not identify any clear linkage between per capita GDP and NMVOCs in Spain. The EKC for $\mathrm{SO}_{x}$ is identified in different countries; in fact List and Gallet (1999) and Millimet, List, and Stengos (2003) validate this hypothesis for the 50 US States. A similar conclusion is reached by Roca et al. (2001) and Fodha and Zaghdoud (2010) for Spain and Tunisia respectively. ${ }^{23}$

Second, as far as we know, our paper is the first attempt in the empirical literature to explicitly study the role of technology in the EKC. It is interesting to note that our estimates generally suggest that innovation negatively influences the turning point of the EKC in a linear way. In fact, the coefficient $\beta_{2}$ proves to be negative and significant in Panels (A)-(C) in Table 5. Coefficients $\beta_{3}$ and $\beta_{4}$ show positive and negative signs respectively, but they do not statistically differ from zero. Columns (3) and (4) for NMVOCS $S_{i t}$ are the exceptions where only the parameter $\beta_{4}$ is statistically significant at $10 \%$ critical level.

Finally, Table 6 reports for each model the indirect estimates of the parameters $\lambda_{0}, \lambda_{1}, \lambda_{2}$, and $\lambda_{3}$ and their standard errors. The parameter $\lambda_{0}$ is positive and statistically different from zero in all the estimates. This confirms the positive sign of coefficient $\beta_{1}$. The inverse relationship between technological progress and the turning point indicated in eq. [6] is confirmed by the sign of the parameter $\lambda_{1}$, which is negative and significant for $C_{i t}$ and $N M V O C S_{i t}$. A less definite conclusion is reached for $S O X_{i t}$, since it is negative but not statistically significant. This last result may depend on the nature of the pollutant, since emissions in part originate from natural events like volcanic eruptions, a phenomenon which can be hardly limited by technological effort. The parameters $\lambda_{2}$ and $\lambda_{3}$ are positive and negative respectively, but they do not differ from zero.

In general, our results indicate that the turning point is an inverse function of the region's level of technological progress, i.e. the turning point in a more innovative region is reached at a lower income level than in a less innovative one, in a sort of "environmental catching up". This finding is in line with Chimeli and Braden (2005), who demonstrate the existence of a critical value of TFP such that higher TFPs (and income) are associated with improvements in environmental quality. On the other hand, as noted by Chimeli (2007), technological progress is a very complex phenomenon and TFP is only one aspect of it.

23 For a more general survey see Stern (2004). 
Table 6: Indirect estimations of the parameters $\lambda_{0}, \lambda_{1}, \lambda_{2}$, and $\lambda_{3}$ of eq. [9] for $\mathrm{CO}_{\text {it }}$ (Panel A),

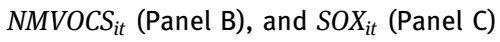

\begin{tabular}{|c|c|c|c|c|}
\hline & (1) & (2) & (3) & (4) \\
\hline \multicolumn{5}{|c|}{ Panel (A) } \\
\hline \multirow{2}{*}{$\lambda_{0}$} & 9.02 & 9.03 & 9.19 & 9.17 \\
\hline & $(0.45)^{\star \star \star}$ & $(0.45)^{\star \star \star}$ & $(0.39)^{\star \star \star}$ & $(0.39)^{\star \star \star}$ \\
\hline \multirow[t]{2}{*}{$\lambda_{1}$} & -0.78 & -0.76 & -0.75 & -0.80 \\
\hline & $(0.31)^{\star \star}$ & $(0.32)^{\star \star}$ & $(0.29)^{\star \star}$ & $(0.35)^{\star \star}$ \\
\hline \multirow[t]{2}{*}{$\lambda_{2}$} & 0.17 & 0.18 & 0.18 & 0.19 \\
\hline & $(0.42)$ & $(0.52)$ & $(0.49)$ & $(0.49)$ \\
\hline \multirow{2}{*}{$\lambda_{3}$} & -0.14 & -0.14 & -0.019 & -0.22 \\
\hline & $(0.19)$ & $(0.19)$ & $(0.19)$ & $(0.21)$ \\
\hline \multicolumn{5}{|c|}{ Panel (B) } \\
\hline \multirow[t]{2}{*}{$\lambda_{0}$} & 9.08 & 9.11 & 9.29 & 9.30 \\
\hline & $(0.53)^{\star \star \star}$ & $(0.50)^{\star \star \star}$ & $(0.42)^{\star \star \star}$ & $(0.40)^{\star \star \star}$ \\
\hline \multirow[t]{2}{*}{$\lambda_{1}$} & -0.90 & -0.85 & -0.84 & -0.98 \\
\hline & $(0.41)^{\star \star}$ & $(0.39)^{\star \star}$ & $(0.36)^{\star \star}$ & $(0.42)^{\star \star}$ \\
\hline \multirow{2}{*}{$\lambda_{2}$} & 0.30 & 0.32 & 0.33 & 0.35 \\
\hline & $(0.66)$ & $(0.64)$ & $(0.58)$ & $(0.57)$ \\
\hline \multirow[t]{2}{*}{$\lambda_{3}$} & -0.31 & -0.28 & -0.36 & -0.43 \\
\hline & $(0.27)$ & $(0.26)$ & $(0.25)$ & $(0.28)$ \\
\hline \multicolumn{5}{|c|}{ Panel (C) } \\
\hline \multirow{2}{*}{$\lambda_{0}$} & 8.56 & 8.61 & 8.81 & 8.85 \\
\hline & $(1.04)^{\star \star \star}$ & $(1.00)^{\star \star \star}$ & $(0.86)^{\star \star \star}$ & $(0.81)^{\star \star \star}$ \\
\hline \multirow[t]{2}{*}{$\lambda_{1}$} & -1.04 & -0.99 & -0.97 & -1.15 \\
\hline & $(0.66)$ & $(0.64)$ & $(0.60)$ & $(0.69)$ \\
\hline \multirow[t]{2}{*}{$\lambda_{2}$} & 0.80 & 0.81 & 0.79 & 0.80 \\
\hline & (1.10) & $(1.08)$ & (1.01) & $(0.97)$ \\
\hline \multirow[t]{2}{*}{$\lambda_{3}$} & 0.04 & 0.04 & 0.04 & -0.15 \\
\hline & $(0.32)$ & $(0.31)$ & $(0.31)$ & $(0.36)$ \\
\hline
\end{tabular}

Notes: Starting from the estimates presented in Table 5, the parameters $\lambda_{0}, \lambda_{1}, \lambda_{2}$, and $\lambda_{3}$ are indirectly computed as follows: $\lambda_{0}=-\frac{\beta_{1}}{\alpha}, \lambda_{1}=-\frac{\beta_{2}}{\alpha}, \lambda_{2}=-\frac{\beta_{3}}{\alpha}$, and $\lambda_{3}=-\frac{\beta_{4}}{\alpha}$; Panels (A)-(C) refer to the estimates obtained when $\mathrm{CO}, \mathrm{NMVOCs}$, and $\mathrm{SO}_{x}$ are considered as dependent variables respectively; Asymptotic standard errors are reported in parentheses; ${ }^{*}$, ${ }^{\star}$, and ${ }^{\star \star \star}$ indicate significance at 10,5 , and $1 \%$ levels.

Other factors, such as efficiency of expenditure on environmental protection and pollution intensity of capital, take on great importance especially in advanced economies, where there are higher levels of environmental awareness, policy makers pay much more attention to environmental protection, and newer and cleaner production methods are introduced. A detailed robustness analysis of our empirical results is thus presented in the following sub-section. 


\subsection{Robustness analyses}

In this sub-section we perform some robustness analyses in order to test the sensitivity of the previous results. Different modifications of our empirical model are proposed. First, we re-estimate eq. [9] by considering an alternative dependent variable, measuring the intensity of pollution as pollution per capita instead of pollution per Euro of GDP. We calculate per capita emission levels for each pollutant, ${ }^{24}$ and we indicate with ${ }^{2} o_{i t}, n_{m v o c s}$ and $s o x_{i t}$ per capita carbon monoxides, per capita non-methane volatile organic compounds, and per capita sulfur oxides. Estimation results for each pollutant are proposed in Table 7 (Panels A-C respectively).

Table 7: Estimation results of eq. [9] for $\mathrm{co}_{i t}$ (Panel A), nmvocs $_{i t}$ (Panel B), and sox $i t$ (Panel C) - fixed effects

(1)

(2)

(3)

(4)

\begin{tabular}{|c|c|c|c|c|}
\hline \multicolumn{5}{|l|}{ Panel (A) } \\
\hline$y_{i} g_{i} t$ & $\begin{array}{l}-0.85^{\star \star \star} \\
(0.25)\end{array}$ & $\begin{array}{l}-0.91^{\star \star \star} \\
(0.25)\end{array}$ & $\begin{array}{l}-0.92^{\star \star \star} \\
(0.25)\end{array}$ & $\begin{array}{l}-0.89^{\star \star \star *} \\
(0.26)\end{array}$ \\
\hline$g_{i} t$ & $\begin{array}{l}7.77^{\star \star \star} \\
(2.65)\end{array}$ & $\begin{array}{l}8.41^{\star \star \star} \\
(2.65)\end{array}$ & $\begin{array}{l}8.53^{\star \star \star} \\
(2.63)\end{array}$ & $\begin{array}{l}8.26^{\star \star \star} \\
(2.67)\end{array}$ \\
\hline$T_{i} g_{i} t$ & $\begin{array}{l}-0.76^{\star \star \star} \\
(0.25)\end{array}$ & $\begin{array}{l}-0.76^{\star \star \star} \\
(0.25)\end{array}$ & $\begin{array}{l}-0.75^{\star \star \star} \\
(0.25)\end{array}$ & $\begin{array}{l}-0.62^{\star} \\
(0.31)\end{array}$ \\
\hline$T_{i}^{2} g_{i} t$ & $\begin{array}{r}0.06 \\
(0.45)\end{array}$ & $\begin{array}{r}0.08 \\
(0.44)\end{array}$ & $\begin{array}{r}0.11 \\
(0.44)\end{array}$ & $\begin{array}{r}0.07 \\
(0.45)\end{array}$ \\
\hline$T_{i}^{3} g_{i} t$ & $\begin{array}{l}-0.13 \\
(0.15)\end{array}$ & $\begin{array}{l}-0.11 \\
(0.15)\end{array}$ & $\begin{array}{l}-0.15 \\
(0.15)\end{array}$ & $\begin{array}{l}-0.08 \\
(0.18)\end{array}$ \\
\hline$E D U_{i t}$ & $\begin{array}{l}-2.51^{\star \star \star} \\
(0.51)\end{array}$ & $\begin{array}{l}-2.78^{\star \star \star} \\
(0.54)\end{array}$ & $\begin{array}{l}-2.62^{\star \star \star} \\
(0.55)\end{array}$ & $\begin{array}{l}-2.57^{\star \star \star} \\
(0.56)\end{array}$ \\
\hline$X_{i t}$ & - & $\begin{array}{r}0.17 \\
(0.12)\end{array}$ & $\begin{array}{l}0.29^{\star} \\
(0.15)\end{array}$ & $\begin{array}{l}0.29^{\star} \\
(0.15)\end{array}$ \\
\hline$M_{i t}$ & - & - & $\begin{array}{l}-0.19 \\
(0.16)\end{array}$ & $\begin{array}{l}-0.11 \\
(0.20)\end{array}$ \\
\hline$M F G_{i t}$ & - & - & - & $\begin{array}{r}0.36 \\
(0.49)\end{array}$ \\
\hline$R^{2}$ & 0.91 & 0.92 & 0.92 & 0.92 \\
\hline Hausman's test & 22.76 & 25.26 & 24.80 & 23.58 \\
\hline$p$-value & 0.00 & 0.00 & 0.00 & 0.00 \\
\hline
\end{tabular}

24 Population data are freely available in the DEMO database from ISTAT, the Italian National Statistics Institute. 
Table 7: (Continued)

\begin{tabular}{|c|c|c|c|c|}
\hline & (1) & (2) & (3) & (4) \\
\hline \multicolumn{5}{|l|}{ Panel (B) } \\
\hline$y_{i} g_{i} t$ & $\begin{array}{l}-0.47^{\star \star} \\
(0.20)\end{array}$ & $\begin{array}{l}-0.55^{\star \star \star} \\
(0.19)\end{array}$ & $\begin{array}{l}-0.55^{\star \star \star} \\
(0.18)\end{array}$ & $\begin{array}{l}-0.55^{\star \star \star} \\
(0.18)\end{array}$ \\
\hline$g_{i} t$ & $\begin{array}{l}4.34^{\star \star} \\
(2.05)\end{array}$ & $\begin{array}{l}5.15^{\star \star} \\
(1.93)\end{array}$ & $\begin{array}{l}5.26^{\star \star \star} \\
(1.87)\end{array}$ & $\begin{array}{l}5.22^{\star \star} \\
(1.92)\end{array}$ \\
\hline$T_{i} g_{i} t$ & $\begin{array}{l}-0.50^{\star \star} \\
(0.19)\end{array}$ & $\begin{array}{l}-0.50^{\star \star \star} \\
(0.18)\end{array}$ & $\begin{array}{l}-0.49^{\star \star \star} \\
(0.18)\end{array}$ & $\begin{array}{l}-0.46^{\star \star} \\
(0.22)\end{array}$ \\
\hline$T_{i}^{2} g_{i} t$ & $\begin{array}{r}0.27 \\
(0.35)\end{array}$ & $\begin{array}{r}0.29 \\
(0.32)\end{array}$ & $\begin{array}{r}0.32 \\
(0.31)\end{array}$ & $\begin{array}{r}0.32 \\
(0.32)\end{array}$ \\
\hline$T_{i}^{3} g_{i} t$ & $\begin{array}{l}-0.25^{\star \star} \\
(0.12)\end{array}$ & $\begin{array}{l}-0.23^{\star \star} \\
(0.11)\end{array}$ & $\begin{array}{l}-0.27^{\star \star} \\
(0.11)\end{array}$ & $\begin{array}{l}-0.26^{\star} \\
(0.13)\end{array}$ \\
\hline$E D U_{i t}$ & $\begin{array}{l}-1.94^{\star \star \star} \\
(0.40)\end{array}$ & $\begin{array}{l}-2.28^{\star \star \star} \\
(0.39)\end{array}$ & $\begin{array}{l}-2.12^{\star \star \star} \\
(0.39)\end{array}$ & $\begin{array}{l}-2.11^{\star \star \star} \\
(0.40)\end{array}$ \\
\hline$X_{i t}$ & - & $\begin{array}{c}0.22^{\star \star} \\
(0.09)\end{array}$ & $\begin{array}{l}0.34^{\star \star \star} \\
(0.11)\end{array}$ & $\begin{array}{l}0.34^{\star \star \star} \\
(0.11)\end{array}$ \\
\hline$M_{i t}$ & - & - & $\begin{array}{l}-0.20^{\star} \\
(0.11)\end{array}$ & $\begin{array}{l}-0.19 \\
(0.14)\end{array}$ \\
\hline$M F G_{i t}$ & - & - & - & $\begin{array}{r}0.07 \\
(0.35)\end{array}$ \\
\hline$R^{2}$ & 0.88 & 0.90 & 0.91 & 0.91 \\
\hline $\begin{array}{l}\text { Hausman's test } \\
p \text {-value }\end{array}$ & $\begin{array}{r}19.86 \\
0.00\end{array}$ & $\begin{array}{r}22.66 \\
0.00\end{array}$ & $\begin{array}{r}22.47 \\
0.00\end{array}$ & $\begin{array}{r}21.86 \\
0.00\end{array}$ \\
\hline Panel (C) & & & & \\
\hline$y_{i} g_{i} t$ & $\begin{array}{l}-1.21 \\
(0.75)\end{array}$ & $\begin{array}{l}-1.33^{*} \\
(0.76)\end{array}$ & $\begin{array}{l}-1.34^{\star} \\
(0.76)\end{array}$ & $\begin{array}{l}-1.37^{\star} \\
(0.78)\end{array}$ \\
\hline$g_{i} t$ & $\begin{array}{l}10.46 \\
(7.76)\end{array}$ & $\begin{array}{l}11.60 \\
(7.90)\end{array}$ & $\begin{array}{r}11.92 \\
(7.88)\end{array}$ & $\begin{array}{r}12.21 \\
(8.07)\end{array}$ \\
\hline$T_{i} g_{i} t$ & $\begin{array}{l}-1.51^{\star \star} \\
(0.74)\end{array}$ & $\begin{array}{l}-1.51^{*} \\
(0.74)\end{array}$ & $\begin{array}{l}-1.47^{\star} \\
(0.74)\end{array}$ & $\begin{array}{l}-1.62^{\star} \\
(0.93)\end{array}$ \\
\hline$T_{i}^{2} g_{i} t$ & $\begin{array}{r}0.96 \\
(1.31)\end{array}$ & $\begin{array}{r}0.99 \\
(1.32)\end{array}$ & $\begin{array}{r}1.08 \\
(1.31)\end{array}$ & $\begin{array}{r}1.12 \\
(1.34)\end{array}$ \\
\hline$T_{i}^{3} g_{i} t$ & $\begin{array}{r}0.11 \\
(0.44)\end{array}$ & $\begin{array}{r}0.15 \\
(0.44)\end{array}$ & $\begin{array}{r}0.04 \\
(0.45)\end{array}$ & $\begin{array}{l}-0.04 \\
(0.55)\end{array}$ \\
\hline$E D U_{i t}$ & $\begin{array}{l}-3.51^{\star \star} \\
(1.50)\end{array}$ & $\begin{array}{l}-3.99^{* *} \\
(1.60)\end{array}$ & $\begin{array}{l}-3.56^{\star \star} \\
(1.64)\end{array}$ & $\begin{array}{l}-3.61^{\star \star} \\
(1.68)\end{array}$ \\
\hline$X_{i t}$ & - & $\begin{array}{r}0.31 \\
(0.36)\end{array}$ & $\begin{array}{r}0.63 \\
(0.46)\end{array}$ & $\begin{array}{r}0.63 \\
(0.47)\end{array}$ \\
\hline$M_{i t}$ & - & - & $\begin{array}{l}-0.54 \\
(0.48)\end{array}$ & $\begin{array}{l}-0.63 \\
(0.59)\end{array}$ \\
\hline$M F G_{i t}$ & - & - & - & $\begin{array}{l}-0.39 \\
(1.47)\end{array}$ \\
\hline$R^{2}$ & 0.77 & 0.78 & 0.78 & 0.79 \\
\hline Hausman's test & 17.50 & 15.89 & 20.90 & 20.54 \\
\hline$p$-value & 0.00 & 0.03 & 0.00 & 0.01 \\
\hline
\end{tabular}

Notes: See Table 5. 
Table 7 confirms the validity of the EKC for the three pollutants since the coefficient $\beta_{0}$ is again negative and highly statistically significant. With regard to the relationship between economic growth (and pollution) and technological progress, estimates in Table 7 confirm a linear formulation of eq. [6] for $\mathrm{Co}_{i t}$ and sox $_{i t}$, given that only the parameter $\beta_{2}$ is statistically significant. With regard to

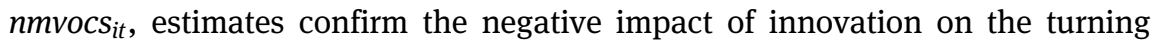
point, but they follow a more complex cubic relationship given the joint significance of the coefficients $\beta_{2}$ and $\beta_{4}$. This is in line with Columns (3) and (4) of Panel (B) in Table 5. Finally, as expected, Hausman's test again rejects the null hypothesis in favor of fixed effects.

Second, we re-estimate eq. [9] for different quantiles of the emission's conditional distribution $\{0.10,0.25,0.50,0.75,0.90\}$, in order to evaluate whether the EKC hypothesis and the technological effect hold across these quantiles. $^{25}$ We proceed following the flexible approach recently proposed by Flores, Flores-Lagunes, and Kapetanakis (2013), where quantile estimations are performed with the inclusion of regional dummy variables, used to introduce fixed effects, which are allowed to vary across quantiles.

Table 8 reports the results for $C_{i t}, N M V O C S_{i t}$, and $S O X_{i t}$ (Panels A-C respectively). In order to save space, we present only estimation results across quantiles related to the specification in Column (4) of Table $5 .{ }^{26}$ It is interesting to note that quantile regressions confirm the existence of the EKC for all the three pollutants: the coefficient $\beta_{0}$ is in fact negative and highly statistically significant. Estimation results again indicate a negative effect of innovation on the turning point of the EKC. In particular, the coefficient $\beta_{2}$ is negative and highly statistically significant across quantiles. Furthermore, while the coefficient $\beta_{3}$ is not generally statistically different from zero (with some exceptions for $C_{i t}$ and $N M V O C S_{i t}$ ), Table 8 also indicates the presence of a negative cubic effect given that $\beta_{4}$ is statistical significant at the conventional critical values. ${ }^{27}$

25 In this context, quantile regression is particularly useful because estimates on the conditional median are more robust than those based on the conditional mean. For details, see Kroenker (2005).

26 Estimates related to the specification in Columns (1)-(3) of Table 5 are available on request from the author.

27 Quantile regression may be biased by the possible absence of monotonicity of the estimated conditional quantile (the so-called "quantile crossing” problem). Chernozhukov, Fernández-Val, and Galichon (2010) develop a methodology in order to rearrange the potentially nonmonotonic estimated quantiles into monotonic ones. A calculation procedure similar to the one developed by Chernozhukov, Fernández-Val, and Galichon (2010) and suitable for the present work, characterized by a high number of relevant regressors (at least five, excluding the control variables), could be particularly interesting for future research. 
Table 8: Quantile estimates of eq. [9] of $C O_{i t}, N M V O C S_{i t}$, and $S O X_{i t}$ (Panels A-C): 10th, 25th, 50th, 75th, and 90th percentiles

\begin{tabular}{|c|c|c|c|c|c|}
\hline & 0.10 & 0.25 & 0.50 & 0.75 & 0.90 \\
\hline \multicolumn{6}{|c|}{ Panel (A) } \\
\hline$y_{i} g_{i} t$ & $\begin{array}{l}-1.08^{\star \star \star} \\
(0.32)\end{array}$ & $\begin{array}{l}-1.20^{\star \star \star} \\
(0.23)\end{array}$ & $\begin{array}{l}-0.98^{\star \star \star} \\
(0.04)\end{array}$ & $\begin{array}{l}-1.13^{\star \star} \\
(0.47)\end{array}$ & $\begin{array}{l}-1.25^{\star \star \star} \\
(0.40)\end{array}$ \\
\hline$g_{i} t$ & $\begin{array}{l}10.40 \star \star \star \\
(3.77)\end{array}$ & $\begin{array}{l}11.17^{\star \star \star} \\
(2.37)\end{array}$ & $\begin{array}{l}8.68^{\star \star \star} \\
(0.38)\end{array}$ & $\begin{array}{c}9.77^{\star \star} \\
(4.70)\end{array}$ & $\begin{array}{l}11.17^{\star \star \star} \\
(3.92)\end{array}$ \\
\hline$T_{i} g_{i} t$ & $\begin{array}{l}-1.51^{\star \star} \\
(0.64)\end{array}$ & $\begin{array}{r}0.12 \\
(0.50)\end{array}$ & $\begin{array}{l}-0.50^{\star \star \star} \\
(0.08)\end{array}$ & $\begin{array}{l}-1.16^{\star \star} \\
(0.47)\end{array}$ & $\begin{array}{l}-1.28^{\star \star \star} \\
(0.23)\end{array}$ \\
\hline$T_{i}^{2} g_{i} t$ & $\begin{array}{r}0.34 \\
(1.72)\end{array}$ & $\begin{array}{l}3.00^{\star \star \star} \\
(0.87)\end{array}$ & $\begin{array}{l}2.59^{\star \star \star} \\
(0.14)\end{array}$ & $\begin{array}{l}-0.27 \\
(0.62)\end{array}$ & $\begin{array}{l}-0.91 \\
(0.86)\end{array}$ \\
\hline$T_{i}^{3} g_{i} t$ & $\begin{array}{l}-1.27^{\star} \\
(0.70)\end{array}$ & $\begin{array}{l}-1.31^{\star \star \star} \\
(0.40)\end{array}$ & $\begin{array}{l}-1.52^{\star \star \star} \\
(0.06)\end{array}$ & $\begin{array}{l}-0.73^{\star \star \star} \\
(0.18)\end{array}$ & $\begin{array}{l}-0.65^{\star \star} \\
(0.25)\end{array}$ \\
\hline$E D U_{i t}$ & $\begin{array}{l}-5.05^{\star \star \star} \\
(0.93)\end{array}$ & $\begin{array}{l}-6.40^{\star \star \star} \\
(1.34)\end{array}$ & $\begin{array}{l}-4.12^{\star \star \star} \\
(0.15)\end{array}$ & $\begin{array}{l}-0.77 \\
(1.20)\end{array}$ & $\begin{array}{l}-1.23 \\
(1.01)\end{array}$ \\
\hline$X_{i t}$ & $\begin{array}{r}0.08 \\
(0.61)\end{array}$ & $\begin{array}{r}0.32 \\
(0.27)\end{array}$ & $\begin{array}{l}-0.20^{\star \star \star} \\
(0.04)\end{array}$ & $\begin{array}{r}0.12 \\
(0.27)\end{array}$ & $\begin{array}{r}0.24 \\
(0.27)\end{array}$ \\
\hline$M_{i t}$ & $\begin{array}{l}-0.36 \\
(0.34)\end{array}$ & $\begin{array}{l}-0.17 \\
(0.32)\end{array}$ & $\begin{array}{l}-0.14^{\star \star \star} \\
(0.05)\end{array}$ & $\begin{array}{l}-0.28 \\
(0.21)\end{array}$ & $\begin{array}{l}-0.50^{\star \star \star} \\
(0.12)\end{array}$ \\
\hline$M F G_{i t}$ & $\begin{array}{l}-0.89 \\
(0.83)\end{array}$ & $\begin{array}{l}-1.13^{\star \star} \\
(0.45)\end{array}$ & $\begin{array}{l}-0.93^{\star \star \star} \\
(0.05)\end{array}$ & $\begin{array}{l}-0.51 \\
(0.32)\end{array}$ & $\begin{array}{l}-0.64^{\star} \\
(0.35)\end{array}$ \\
\hline Panel ( & & & & & \\
\hline$y_{i} g_{i} t$ & $\begin{array}{l}-0.47^{\star \star \star} \\
(0.10)\end{array}$ & $\begin{array}{l}-0.52^{\star \star \star} \\
(0.14)\end{array}$ & $\begin{array}{l}-0.53^{\star \star \star} \\
(0.13)\end{array}$ & $\begin{array}{l}-0.50^{\star \star \star} \\
(0.01)\end{array}$ & $\begin{array}{l}-0.49^{\star \star \star} \\
(0.02)\end{array}$ \\
\hline$g_{i} t$ & $\begin{array}{l}3.26^{\star \star \star} \\
(0.84)\end{array}$ & $\begin{array}{l}5.27^{\star \star \star} \\
(1.49)\end{array}$ & $\begin{array}{l}4.82^{\star \star \star} \\
(1.33)\end{array}$ & $\begin{array}{l}3.59^{\star \star \star} \\
(0.13)\end{array}$ & $\begin{array}{l}3.36^{\star \star \star} \\
(0.22)\end{array}$ \\
\hline$T_{i} g_{i} t$ & $\begin{array}{l}-0.50^{\star} \\
(0.27)\end{array}$ & $\begin{array}{l}-1.33^{\star \star \star} \\
(0.19)\end{array}$ & $\begin{array}{l}-0.91^{\star \star \star} \\
(0.23)\end{array}$ & $\begin{array}{l}-1.16^{\star \star \star} \\
(0.02)\end{array}$ & $\begin{array}{l}-1.22^{\star \star \star} \\
(0.04)\end{array}$ \\
\hline$T_{i}^{2} g_{i} t$ & $\begin{array}{l}-0.10 \\
(0.29)\end{array}$ & $\begin{array}{l}-0.66^{\star} \\
(0.35)\end{array}$ & $\begin{array}{r}0.59 \\
(0.39)\end{array}$ & $\begin{array}{l}0.75^{\star \star \star} \\
(0.05)\end{array}$ & $\begin{array}{l}0.87^{\star \star \star} \\
(0.07)\end{array}$ \\
\hline$T_{i}^{3} g_{i} t$ & $\begin{array}{l}-0.15 \\
(0.17)\end{array}$ & $\begin{array}{l}-0.36^{\star \star} \\
(0.16)\end{array}$ & $\begin{array}{l}-0.60^{\star \star \star} \\
(0.16)\end{array}$ & $\begin{array}{l}-0.72^{\star \star \star} \\
(0.02)\end{array}$ & $\begin{array}{l}-0.79^{\star \star \star} \\
(0.02)\end{array}$ \\
\hline$E D U_{i t}$ & $\begin{array}{l}-0.82 \\
(0.63)\end{array}$ & $\begin{array}{l}-4.78^{\star \star \star} \\
(0.77)\end{array}$ & $\begin{array}{l}-3.75^{\star \star \star} \\
(0.57)\end{array}$ & $\begin{array}{l}-2.61^{\star \star \star} \\
(0.06)\end{array}$ & $\begin{array}{l}-2.34^{\star \star \star} \\
(0.08)\end{array}$ \\
\hline$X_{i t}$ & $\begin{array}{l}-0.24^{\star} \\
(0.12)\end{array}$ & $\begin{array}{l}-0.04 \\
(0.19)\end{array}$ & $\begin{array}{r}0.01 \\
(0.15)\end{array}$ & $\begin{array}{l}0.05^{\star \star} \\
(0.02)\end{array}$ & $\begin{array}{l}0.08^{\star \star} \\
(0.03)\end{array}$ \\
\hline$M_{i t}$ & $\begin{array}{r}0.07 \\
(0.12)\end{array}$ & $\begin{array}{l}-0.34^{\star \star \star} \\
(0.12)\end{array}$ & $\begin{array}{l}-0.42^{\star \star \star} \\
(0.10)\end{array}$ & $\begin{array}{l}-0.08^{\star \star \star} \\
(0.01)\end{array}$ & $\begin{array}{l}-0.13^{\star \star \star} \\
(0.02)\end{array}$ \\
\hline$M F G_{i t}$ & $\begin{array}{r}0.28 \\
(0.47)\end{array}$ & $\begin{array}{l}-1.25^{\star \star \star} \\
(0.23)\end{array}$ & $\begin{array}{l}-0.79^{\star \star \star} \\
(0.20)\end{array}$ & $\begin{array}{l}-1.03^{\star \star \star} \\
(0.03)\end{array}$ & $\begin{array}{l}-1.02^{\star \star \star} \\
(0.04)\end{array}$ \\
\hline
\end{tabular}


Table 8: (Continued)

\begin{tabular}{llllll}
\hline & \multicolumn{1}{c}{$\mathbf{0 . 1 0}$} & $\mathbf{0 . 2 5}$ & $\mathbf{0 . 5 0}$ & $\mathbf{0 . 7 5}$ & $\mathbf{0 . 9 0}$ \\
\hline Panel (C) & & & & & \\
$y_{i} g_{i} t$ & $-1.18^{\star \star}$ & $-0.83^{\star \star}$ & $-1.30^{\star}$ & $-0.87^{\star \star \star}$ & $-0.86^{\star \star \star}$ \\
& $(0.54)$ & $(0.33)$ & $(0.70)$ & $(0.14)$ & $(0.24)$ \\
$g_{i} t$ & $10.86^{\star \star}$ & $7.24^{\star \star}$ & 10.32 & $6.11^{\star \star \star}$ & $5.04^{\star \star}$ \\
& $(4.82)$ & $(3.11)$ & $(6.85)$ & $(1.42)$ & $(2.32)$ \\
$T_{i} g_{i} t$ & $-1.18^{\star \star \star}$ & $-1.90^{\star \star \star}$ & $-2.13^{\star \star}$ & $-2.85^{\star \star \star}$ & $-2.26^{\star \star \star}$ \\
& $(0.41)$ & $(0.64)$ & $(0.97)$ & $(0.25)$ & $(0.35)$ \\
$T_{i}{ }^{2} g_{i} t$ & 0.12 & -0.04 & 1.81 & -0.35 & -0.41 \\
& $(1.66)$ & $(1.18)$ & $(2.18)$ & $(0.40)$ & $(1.05)$ \\
$T_{i}{ }^{3} g_{i} t$ & -0.79 & $-1.11^{\star \star}$ & $-1.51^{\star \star}$ & $-0.71^{\star \star \star}$ & $-0.88^{\star \star \star}$ \\
& $(0.49)$ & $(0.46)$ & $(0.74)$ & $(0.10)$ & $(0.24)$ \\
$E D U_{i t}$ & $-8.57^{\star \star \star}$ & $-7.10^{\star \star \star}$ & -4.24 & $-4.59^{\star \star \star}$ & 0.50 \\
& $(1.16)$ & $(2.17)$ & $(2.90)$ & $(0.40)$ & $(0.73)$ \\
$X_{i t}$ & $1.89^{\star \star \star}$ & $1.87^{\star \star \star}$ & $1.22^{\star}$ & $1.22^{\star \star \star}$ & -0.31 \\
& $(0.27)$ & $(0.48)$ & $(0.65)$ & $(0.11)$ & $(0.35)$ \\
$M_{i t}$ & $-0.59^{\star \star}$ & $-0.78^{\star \star}$ & -0.29 & 0.00 & -0.10 \\
& $(0.27)$ & $(0.33)$ & $(0.48)$ & $(0.10)$ & $(0.24)$ \\
$M F G_{i t}$ & $-3.18^{\star \star \star}$ & $-3.25^{\star \star \star}$ & $-2.22^{\star \star}$ & $-2.86^{\star \star \star}$ & $-1.52^{\star \star \star}$ \\
& $(0.42)$ & $(0.62)$ & $(0.90)$ & $(0.14)$ & $(0.30)$ \\
\hline
\end{tabular}

Notes: All the estimates are performed with the inclusion of regional dummies; See also Table 5.

Finally, with regard to the control variables, in general $E D U_{i t}$ is significant with the expected negative sign for all the pollutants, while $X_{i t}$ is positive and significant for $S O X_{i t}$ and for NMVOCS it limited to the 0.75th and 0.90th quantile. On the other hand, in the case of this last pollutant, $M_{i t}$ is negative as expected and statistically significant. Less clear evidence is found for $\mathrm{CO}_{i t}$ and $S O X_{i t}$. The variable $M F G_{i t}$ is generally significant in the case of $N M V O C S_{i t}$ and $S O X_{i t}$ but with a negative sign.

Indirect estimates of the parameters $\lambda_{0}, \lambda_{1}, \lambda_{2}$, and $\lambda_{3}$ of Tables 7 and 8 are presented in Table 9. The "environmental catching up" hypothesis is confirmed since parameter $\lambda_{1}$ is significant and negative. With regard to quantile regressions, it is worth noting that they show negative and statistically significant values of the parameter $\lambda_{1}$ for all the pollutants. Furthermore, parameter $\lambda_{3}$ in eq. [6] is in general negative and significant across quantiles $\left(\lambda_{3}<0\right)$, given that the coefficient $\beta_{4}$ in Table 8 is negative and statistically different from zero $\left(\beta_{4}<0\right)$. This result strengthens the previous conclusions: indeed, since our estimates indicate that the coefficients $\lambda_{1}$ and $\lambda_{3}$ are jointly negative and significant, eq. [6] suggests that the turning point of the EKC is a decreasing function of the technological progress given that the first derivate of eq. [6] 
Table 9: Indirect estimations of the parameters $\lambda_{0}, \lambda_{1}, \lambda_{2}$, and $\lambda_{3}$ from Tables 7 and 8

\begin{tabular}{lllll}
\hline$\lambda_{0}$ & $\lambda_{1}$ & $\lambda_{2}$ & $\lambda_{3}$ \\
\hline
\end{tabular}

\section{Panel (A)}

Estimates from Table 7

$\begin{array}{cclrr}\text { (1) } & 9.19 & -0.90 & 0.07 & -0.15 \\ & (0.40)^{\star \star \star} & (0.34)^{\star \star} & (0.53) & (0.19) \\ \text { (2) } & 9.25 & -0.84 & 0.08 & -0.12 \\ & (0.36)^{\star \star \star} & (0.31)^{\star \star} & (0.49) & (0.17) \\ \text { (3) } & 9.31 & -0.82 & 0.12 & -0.16 \\ & (0.34)^{\star \star \star} & (0.30)^{\star \star} & (0.49) & (0.18) \\ \text { (4) } & 9.30 & -0.70 & 0.08 & -0.09 \\ & (0.36)^{\star \star \star} & (0.34)^{\star} & (0.51) & (0.21)\end{array}$

Estimates from Table 8

Quantiles

$\begin{array}{lcccc}0.10 & 9.61 & -1.39 & 0.31 & -1.17 \\ & (0.84)^{\star \star \star} & (0.88)^{\star \star \star} & (1.64) & (0.92) \\ 0.25 & 9.31 & 0.09 & 2.50 & -1.09 \\ & (0.37)^{\star \star \star} & (0.41) & (0.83)^{\star \star \star} & (0.43)^{\star \star} \\ 0.50 & 8.89 & -0.51 & 2.65 & -1.56 \\ & (0.05)^{\star \star \star} & (0.08)^{\star \star \star} & (0.15)^{\star \star \star} & (0.08)^{\star \star \star} \\ 0.75 & 8.62 & -1.02 & -0.23 & -0.64 \\ & (0.68)^{\star \star \star} & (0.48)^{\star \star \star} & (0.55) & (0.32)^{\star} \\ 0.90 & 8.92 & -1.02 & -0.72 & -0.51 \\ & (0.34)^{\star \star \star} & (0.31)^{\star \star \star} & (0.82) & (0.19)^{\star \star}\end{array}$

\section{Panel (B)}

Estimates from Table 7

$\begin{array}{cclrl}\text { (1) } & 9.29 & -1.07 & 0.58 & -0.54 \\ & (0.53)^{\star \star \star} & (0.52)^{\star \star \star} & (0.84) & (0.38) \\ \text { (2) } & 9.39 & -0.91 & 0.53 & -0.41 \\ & (0.39)^{\star \star \star} & (0.38)^{\star \star \star} & (0.65) & (0.27) \\ \text { (3) } & 9.49 & -0.87 & 0.58 & -0.49 \\ & (0.35)^{\star \star \star} & (0.36)^{\star \star \star} & (0.64) & (0.28)^{\star} \\ \text { (4) } & 9.49 & -0.84 & 0.58 & -0.46 \\ & (0.36)^{\star \star \star} & (0.41)^{\star} & (0.65) & (0.30)\end{array}$

Estimates from Table 8

Quantiles

\begin{tabular}{lclcc}
0.10 & 6.91 & -1.07 & -0.22 & -0.32 \\
0.25 & $(0.60)^{\star \star \star}$ & $(0.47)^{\star \star}$ & $(0.62)$ & $(0.33)$ \\
& 10.11 & -2.54 & -1.27 & -0.69 \\
0.50 & $(0.58)^{\star \star \star}$ & $(0.75)^{\star \star}$ & $(0.68)^{\star}$ & $(0.40)$ \\
& 9.18 & -1.72 & 1.12 & -1.15 \\
& $(0.40)^{\star \star \star}$ & $(0.56)^{\star \star \star}$ & $(0.77)$ & $(0.41)^{\star \star \star}$ \\
\hline
\end{tabular}


Table 9: (Continued)

\begin{tabular}{ccccc}
\hline & $\lambda_{0}$ & \multicolumn{1}{c}{$\lambda_{\mathbf{1}}$} & \multicolumn{1}{c}{$\lambda_{\mathbf{2}}$} & $\lambda_{\mathbf{3}}$ \\
\hline 0.75 & 7.24 & -2.33 & 1.52 & 1.44 \\
& $(0.07)^{\star \star \star}$ & $(0.07)^{\star \star \star}$ & $(0.08)^{\star \star \star}$ & $(0.04)^{\star \star \star}$ \\
0.90 & 6.89 & -2.51 & 1.79 & -1.61 \\
& $(0.16)^{\star \star \star}$ & $(0.15)^{\star \star \star}$ & $(0.13)^{\star \star \star}$ & $(0.08)^{\star \star \star}$
\end{tabular}

Panel (C)

Estimates from Table 7

(1)

(2)

(3)

(4)
8.63

$(1.14)^{\star \star \star}$

8.74

$(0.99)^{\star \star \star}$

8.86

$(0.92)^{\star \star \star}$

8.88

$(0.90)^{\star \star \star}$
$-1.24$

(0.83)

$-1.13$

(0.73)

$-1.09$

(0.70)

$-1.18$

(0.78)
0.79

(1.29)

0.74

(1.18)

0.80

(1.18)

0.82

(1.17)
0.09

(0.35)

0.11

(0.32)

0.02

(0.32)

$-0.03$

(0.40)

Estimates from Table 8

Quantiles

\begin{tabular}{lclrl}
0.10 & 9.16 & -0.99 & 0.10 & -0.66 \\
& $(0.39)^{\star \star \star}$ & $(0.42)^{\star \star}$ & $(1.37)$ & $(0.30)^{\star \star}$ \\
0.25 & 8.69 & -2.28 & -0.04 & -1.33 \\
& $(0.92)^{\star \star \star}$ & $(1.00)^{\star \star}$ & $(1.41)$ & $(0.70)^{\star}$ \\
0.50 & 7.96 & -1.64 & 1.39 & -1.17 \\
& $(1.19)^{\star \star \star}$ & $(1.00)$ & $(1.70)$ & $(0.78)$ \\
0.75 & 7.01 & -3.26 & -0.39 & -0.81 \\
& $(0.53)^{\star \star \star}$ & $(0.53)^{\star \star \star}$ & $(0.45)$ & $(0.53)^{\star \star \star}$ \\
0.90 & 5.83 & -2.60 & -0.47 & -1.02 \\
& $(1.08)^{\star \star \star}$ & $(0.89)^{\star \star \star}$ & $(1.30)$ & $(0.27)^{\star \star \star}$ \\
\hline
\end{tabular}

Notes: Rows called (1)-(4) and $0.10,0.25,0.50,0.75$, and 0.90 refer to the indirect estimates of the parameters $\lambda_{0}, \lambda_{1}, \lambda_{2}$, and $\lambda_{3}$ obtained from results proposed in columns from (1) to (4) and from 0.10 to 0.90 in Tables 7 and 8 respectively; Panels (A)-(C) refer to the estimates obtained when CO, NMVOCs, and $\mathrm{SO}_{x}$ are considered as dependent variables respectively; Asymptotic standard errors are reported in parentheses; ${ }^{*}{ }^{\star \star}$, and ${ }^{\star \star \star}$ indicate significance at 10,5 , and $1 \%$ levels.

with respect to $T$ is negative. So, if $T>0$, promoting innovation becomes an important goal for the policymaker, in the light of its positive effects in terms of environmental quality and economic growth. ${ }^{28}$

To conclude, these results validate the EKC hypothesis in the 20 regions of Italy, and they confirm that technological progress negatively influences the EKC. A

28 Estimates for $N_{M V O C S_{i t}}$ also show that the coefficients $\lambda_{2}$ and $\lambda_{3}$ are statistically significant at the extreme quantiles of the distribution. 
more general negative cubic relationship emerges especially when quantile regressions are computed. It is worth noting that this is also in line with the theoretical findings by Chimeli (2007), who demonstrates that there is a non-monotonic relationship between technological progress and the turning point of the EKC.

\section{An additional analysis: the case of Italy}

Given that technological progress is not an immediate phenomenon, but it takes time, our results may be affected by the short time series used. To the best of our knowledge, pollution data do not exist at regional level for a longer time period. Consequently, in order to investigate this last point, we construct a new database considering the case of Italy at aggregate instead of regional level. Pollution data are available at national level on the ISPRA website for the time period 1980-2011. In this way, we can verify if the EKC is observed for the whole economy and if technology has roughly the same impact at national as at regional level. This analysis is performed using time series data. Since the specification proposed by Bradford et al. (2005) is explicitly conceived for panel data, some modification of eq. [9] is required in order to adapt it to the absence of the cross-sectional dimension. In particular, in this case, we do not use average values of $g, T$, and $y$, which are instead treated as time-varying variables $\left(g_{t}, T_{t}\right.$, and $\left.y_{t}\right)$. Moreover, to the best of our knowledge, this analysis is new in the literature, since, as noted in the previous sections, there is only one paper that studies the EKC hypothesis for Italy using a time series approach (Cialani 2007). ${ }^{29}$ We thus estimate the following equation:

$$
p_{t}=\mu+\gamma_{0}\left(y_{t} g_{t} t\right)+\gamma_{1}\left(g_{t} t\right)+\gamma_{2}\left(T_{t} g_{t} t\right)+\gamma_{3}\left(T_{t}^{2} g_{t} t\right)+\gamma_{4}\left(T_{t}^{3} g_{t} t\right)+\gamma_{5} Z_{t}+\epsilon_{t},
$$

where the EKC hypothesis is verified if the coefficient $\gamma_{0}$ is negative $\left(\gamma_{0}<0\right)$. The technological effect on the turning point is measured by the parameters $\gamma_{1}, \gamma_{2}, \gamma_{3}$, and $\gamma_{4}$. The variable $g_{t}$ is computed according to the same two-step procedure proposed for the regional case. ${ }^{30}$ Table 10 shows the results.

29 For more details, see Section 2.

30 Unit-root tests and the estimates related to eq. [10] are available on request. In particular, when necessary, variables in eq. [10] are transformed in first difference. In this context, eq. [10] is estimated with the inclusion of a dummy variable for the year 2009 (in order to capture the negative effect of the recent economic crisis). Finally, following the indications provided by diagnostic statistics and because of the insignificant values of the control variable $\operatorname{LIFE}_{t}$, we have chosen Specification (b) instead of (d). 


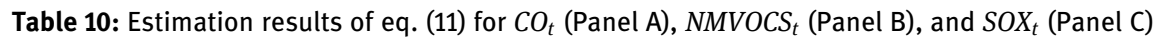
in the case of Italy

\begin{tabular}{|c|c|c|c|c|}
\hline & (1) & (2) & (3) & (4) \\
\hline \multicolumn{5}{|c|}{ Panel (A) } \\
\hline$g_{t} y_{t} t$ & $\begin{array}{l}-0.25^{\star \star \star} \\
(0.05)\end{array}$ & $\begin{array}{l}-0.27^{\star \star \star} \\
(0.06)\end{array}$ & $\begin{array}{l}-0.31^{\star \star \star} \\
(0.05)\end{array}$ & $\begin{array}{l}-0.32^{\star \star \star} \\
(0.05)\end{array}$ \\
\hline$g_{t} t$ & $\begin{array}{l}2.43^{\star \star \star} \\
(0.50)\end{array}$ & $\begin{array}{l}2.60^{\star \star \star} \\
(0.56)\end{array}$ & $\begin{array}{l}2.93^{\star \star \star} \\
(0.51)\end{array}$ & $\begin{array}{l}3.06^{\star \star \star} \\
(0.46)\end{array}$ \\
\hline$T_{t} g_{t} t$ & $\begin{array}{l}-0.31^{\star} \\
(0.17)\end{array}$ & $\begin{array}{l}-0.26 \\
(0.19)\end{array}$ & $\begin{array}{l}-0.14 \\
(0.17)\end{array}$ & $\begin{array}{l}-0.12 \\
(0.15)\end{array}$ \\
\hline$T_{t}^{2} g_{t} t$ & $\begin{array}{l}5.79^{\star \star \star \star} \\
(1.96)\end{array}$ & $\begin{array}{l}5.70^{\star \star \star *} \\
(1.99)\end{array}$ & $\begin{array}{c}3.72^{\star} \\
(1.92)\end{array}$ & $\begin{array}{l}3.80^{\star \star} \\
(1.70)\end{array}$ \\
\hline$T_{t}^{3} g_{t} t$ & $\begin{array}{l}-21.30^{\star \star \star} \\
(6.25)\end{array}$ & $\begin{array}{l}-21.75^{\star \star \star} \\
(6.37)\end{array}$ & $\begin{array}{c}-15.12^{\star \star} \\
(6.19)\end{array}$ & $\begin{array}{c}-15.84^{\star \star \star \star} \\
(5.48)\end{array}$ \\
\hline$E D U_{t}$ & $\begin{array}{r}0.12 \\
(0.09)\end{array}$ & $\begin{array}{r}0.12 \\
(0.09)\end{array}$ & $\begin{array}{r}0.05 \\
(0.08)\end{array}$ & $\begin{array}{r}0.06 \\
(0.07)\end{array}$ \\
\hline$X_{t}$ & & $\begin{array}{r}1.52 \\
(2.29)\end{array}$ & $\begin{array}{c}5.81^{\star \star} \\
(2.62)\end{array}$ & $\begin{array}{l}7.55^{\star \star \star} \\
(2.42)\end{array}$ \\
\hline$M_{t}$ & & & $\begin{array}{l}-5.47^{\star \star} \\
(2.12)\end{array}$ & $\begin{array}{l}-4.24^{\star \star} \\
(1.94)\end{array}$ \\
\hline$M F G_{t}$ & & & & $\begin{array}{l}-11.21^{\star \star} \\
(4.46)\end{array}$ \\
\hline$R^{2}$ & 0.74 & 0.74 & 0.81 & 0.86 \\
\hline \multicolumn{5}{|c|}{ Panel (B) } \\
\hline$g_{t} y_{t} t$ & $\begin{array}{l}-0.20^{\star \star \star} \\
(0.04)\end{array}$ & $\begin{array}{l}-0.22^{\star \star \star} \\
(0.05)\end{array}$ & $\begin{array}{l}-0.24^{\star \star \star} \\
(0.05)\end{array}$ & $\begin{array}{l}-0.25^{\star \star \star} \\
(0.04)\end{array}$ \\
\hline$g_{t} t$ & $\begin{array}{l}1.93^{\star \star \star} \\
(0.42)\end{array}$ & $\begin{array}{l}2.07^{\star \star \star \star} \\
(0.48)\end{array}$ & $\begin{array}{l}2.33^{\star \star \star} \\
(0.45)\end{array}$ & $\begin{array}{l}2.44^{\star \star \star} \\
(0.40)\end{array}$ \\
\hline$T_{t} g_{t} t$ & $\begin{array}{l}-0.28^{\star} \\
(0.15)\end{array}$ & $\begin{array}{l}-0.24 \\
(0.16)\end{array}$ & $\begin{array}{l}-0.15 \\
(0.15)\end{array}$ & $\begin{array}{l}-0.13 \\
(0.13)\end{array}$ \\
\hline$T_{t}^{2} g_{t} t$ & $\begin{array}{l}5.10^{\star \star \star} \\
(1.66)\end{array}$ & $\begin{array}{l}5.03^{\star \star \star} \\
(1.69)\end{array}$ & $\begin{array}{l}3.48^{\star} \\
(1.67)\end{array}$ & $\begin{array}{l}3.55^{\star \star} \\
(1.48)\end{array}$ \\
\hline$T_{t}^{3} g_{t} t$ & $\begin{array}{c}-18.45^{\star \star \star} \\
(5.29)\end{array}$ & $\begin{array}{c}-18.81^{\star \star \star} \\
(5.40)\end{array}$ & $\begin{array}{c}-13.62^{\star \star} \\
(5.37)\end{array}$ & $\begin{array}{c}-14.23^{\star \star \star} \\
(4.79)\end{array}$ \\
\hline$E D U_{t}$ & $\begin{array}{r}0.08 \\
(0.08)\end{array}$ & $\begin{array}{r}0.07 \\
(0.08)\end{array}$ & $\begin{array}{r}0.02 \\
(0.07)\end{array}$ & $\begin{array}{r}0.03 \\
(0.07)\end{array}$ \\
\hline$X_{t}$ & & $\begin{array}{r}1.24 \\
(1.94)\end{array}$ & $\begin{array}{l}4.59^{\star} \\
(2.27)\end{array}$ & $\begin{array}{l}6.08^{\star * \star} \\
(2.11)\end{array}$ \\
\hline$M_{t}$ & & & $\begin{array}{l}-4.28^{\star \star} \\
(1.85)\end{array}$ & $\begin{array}{l}-3.23^{\star} \\
(1.70)\end{array}$ \\
\hline$M F G_{t}$ & & & & $\begin{array}{l}-9.56^{\star \star} \\
(3.90)\end{array}$ \\
\hline$R^{2}$ & 0.72 & 0.73 & 0.79 & 0.84 \\
\hline
\end{tabular}


Table 10: (Continued)

\begin{tabular}{lcccc}
\hline & $(1)$ & $(2)$ & $(3)$ & $(4)$ \\
\hline Panel (C) & & & & \\
$g_{t} y_{t} t$ & $-0.39^{\star \star \star}$ & $-0.43^{\star \star \star}$ & $-0.48^{\star \star \star}$ & $-0.50^{\star \star \star}$ \\
& $(0.08)$ & $(0.09)$ & $(0.09)$ & $(0.07)$ \\
$g_{t} t$ & $3.75^{\star \star \star}$ & $4.06^{\star \star \star}$ & $4.57^{\star \star \star}$ & $4.79^{\star \star \star}$ \\
& $(0.79)$ & $(0.90)$ & $(0.83)$ & $(0.71)$ \\
$T_{t} g_{t} t$ & $-0.51^{\star}$ & -0.43 & -0.24 & -0.20 \\
& $(0.27)$ & $(0.30)$ & $(0.28)$ & $(0.23)$ \\
$T_{t}{ }^{2} g_{t} t$ & $9.84^{\star \star \star}$ & $9.68^{\star \star \star}$ & $6.64^{\star \star}$ & $6.78^{\star \star}$ \\
& $(3.13)$ & $(3.17)$ & $(3.09)$ & $(2.63)$ \\
$T_{t}{ }^{3} g_{t} t$ & $-35.79^{\star \star \star}$ & $-36.58^{\star \star \star}$ & $-26.39^{\star \star}$ & $-27.67^{\star \star \star}$ \\
& $(9.97)$ & $(10.14)$ & $(9.96)$ & $(8.48)$ \\
$E D U_{t}$ & 0.14 & 0.12 & 0.03 & 0.04 \\
& $(0.14)$ & $(0.15)$ & $(0.14)$ & $(0.12)$ \\
$X_{t}$ & & 2.72 & $9.31^{\star \star}$ & $12.39^{\star \star \star}$ \\
& & $(3.64)$ & $(4.22)$ & $(3.74)$ \\
$M_{t}$ & & & $-8.40^{\star \star}$ & $-6.23^{\star}$ \\
& & & $(3.42)$ & $(3.01)$ \\
$M F G_{t}$ & & & & $-19.87^{\star \star}$ \\
& & & & $(6.91)$ \\
$R^{2}$ & 0.72 & 0.73 & 0.79 & 0.86 \\
\hline
\end{tabular}

Notes: Panels (A)-(C) refer to the estimates obtained when $\mathrm{CO}, \mathrm{NMVOCS}$, and $\mathrm{SO}_{x}$ are considered as dependent variables respectively; All the estimates are performed with the inclusion of time dummies for the years 1986 and 2009; Asymptotic standard errors are reported in parentheses; ${ }^{*},{ }^{\star *}$, and ${ }^{\star \star \star}$ indicate significance at 10,5 , and $1 \%$ levels; $y_{t} g_{t} t, g_{t} t$, $T_{t} g_{t} t, T_{t}^{2} g_{t} t$, and $T_{t}{ }^{3} g_{t} t$ are computed considering the log transformation of $Y_{t}$ and $T_{t}$; All the other variables are in log.

The EKC hypothesis is verified, given that the coefficient $\gamma_{0}$ is negative and statistically significant for the three pollutants. ${ }^{31}$ With regard to the technological parameters $\left(\gamma_{1}, \gamma_{2}, \gamma_{3}\right.$, and $\left.\gamma_{4}\right)$, it is worth noting that they take the same sign identified for the 20 regions of Italy (alternatively positive and negative respectively), although some differences emerge. First, the linear relationship introduced by parameter $\gamma_{2}$ is not in general observed, with Column (1) as the only exception. In fact, although $\gamma_{2}$ is negative, it is not statistically significant at the conventional critical values. On the other hand, the quadratic and cubic terms $\left(\gamma_{3}\right.$ and $\gamma_{4}$ respectively) assume positive and negative statistically significant values. This implies a cubic relationship between innovation and the turning point of the

31 With regard to the control variables, only $X_{t}$ and $M_{t}$ are significant and with the expected positive and negative signs, while $M F G_{t}$ is significant, but again with a negative sign. 
EKC, but it is more complex than for the regional case, where the statistically significant parameters were $\beta_{2}$ and, especially for the quantile regressions, $\beta_{4}$, both with negative signs. This result is also supported by the indirect estimations of the parameters $\lambda_{0}, \lambda_{1}, \lambda_{2}$, and $\lambda_{3}$ in Table 11, where only $\lambda_{2}$ and $\lambda_{3}$ assume statistically significant values with positive and negative signs respectively. ${ }^{32}$

Table 11: Indirect estimations of the parameters $\lambda_{0}, \lambda_{1}, \lambda_{2}$, and $\lambda_{3}$ for the case of Italy

\begin{tabular}{|c|c|c|c|c|}
\hline & (1) & (2) & (3) & (4) \\
\hline \multicolumn{5}{|c|}{ Panel (A) } \\
\hline \multirow[t]{2}{*}{$\lambda_{0}$} & 9.55 & 9.55 & 9.57 & 9.58 \\
\hline & $(0.03)^{\star \star \star}$ & $(0.03)^{\star \star \star}$ & $(0.03)^{\star \star \star}$ & $(0.02)^{\star \star \star}$ \\
\hline \multirow[t]{2}{*}{$\lambda_{1}$} & -1.21 & -0.97 & -0.45 & -0.37 \\
\hline & $(0.79)$ & $(0.79)$ & $(0.59)$ & $(0.50)$ \\
\hline \multirow[t]{2}{*}{$\lambda_{2}$} & 22.77 & 20.95 & 12.15 & 11.89 \\
\hline & $(9.38)^{\star \star}$ & $(9.05)^{\star \star}$ & $(7.02)$ & $(5.93)^{\star}$ \\
\hline \multirow[t]{2}{*}{$\lambda_{3}$} & -83.84 & -79.98 & -49.36 & -49.59 \\
\hline & $(29.86)^{\star \star}$ & $(28.38)^{\star \star}$ & $(22.42)^{\star \star}$ & $(19.01)^{\star \star}$ \\
\hline \multicolumn{5}{|c|}{ Panel (B) } \\
\hline \multirow[t]{2}{*}{$\lambda_{0}$} & 9.55 & 9.55 & 9.57 & 9.58 \\
\hline & $(0.03)^{\star \star \star}$ & $(0.03)^{\star \star \star}$ & $(0.03)^{\star \star \star}$ & $(0.03)^{\star \star \star}$ \\
\hline \multirow[t]{2}{*}{$\lambda_{1}$} & -1.38 & -1.13 & -0.60 & -0.58 \\
\hline & $(0.86)$ & $(0.87)$ & $(0.67)$ & $(0.56)$ \\
\hline \multirow[t]{2}{*}{$\lambda_{2}$} & 25.24 & 23.22 & 14.31 & 13.93 \\
\hline & $(10.31)^{\star \star}$ & $(9.96)^{\star \star}$ & $(7.87)^{\star}$ & $(6.66)^{\star}$ \\
\hline \multirow[t]{2}{*}{$\lambda_{3}$} & -91.33 & -86.89 & -55.96 & -55.92 \\
\hline & $(32.75)^{\star \star}$ & $(31.14)^{\star \star}$ & $(25.03)^{\star \star}$ & $(21.32)^{\star \star}$ \\
\hline \multicolumn{5}{|c|}{ Panel (C) } \\
\hline \multirow[t]{2}{*}{$\lambda_{0}$} & 9.55 & 9.54 & 9.56 & 9.57 \\
\hline & $(0.03)^{\star \star \star}$ & $(0.03)^{\star \star \star}$ & $(0.03)^{\star \star \star}$ & $(0.02)^{\star \star \star}$ \\
\hline \multirow[t]{2}{*}{$\lambda_{1}$} & -1.29 & -1.00 & -0.49 & -0.40 \\
\hline & $(0.82)$ & $(0.81)$ & $(0.62)$ & $(0.60)$ \\
\hline \multirow[t]{2}{*}{$\lambda_{2}$} & 25.01 & 22.76 & 13.90 & 13.53 \\
\hline & $(9.95)^{\star \star}$ & $(9.46)^{\star \star}$ & $(7.40)^{\star \star}$ & $(5.97)^{\star \star}$ \\
\hline \multirow[t]{2}{*}{$\lambda_{3}$} & -91.00 & -86.05 & -55.23 & -55.22 \\
\hline & $(31.67)^{\star \star \star}$ & $(29.68)^{\star \star \star}$ & $(23.62)^{\star \star}$ & $(19.15)^{\star \star}$ \\
\hline
\end{tabular}

Notes: Starting from the estimates presented in Table 10 , the parameters $\lambda_{0}, \lambda_{1}, \lambda_{2}$, and $\lambda_{3}$ are indirectly computed as follows: $\lambda_{0}=-\frac{\gamma_{1}}{\alpha}, \lambda_{1}=-\frac{\gamma_{2}}{\alpha}, \lambda_{2}=-\frac{\gamma_{3}}{\alpha}$, and $\lambda_{3}=-\frac{\gamma_{4}}{\alpha}$; Panels (A)-(C) refer to the estimates obtained when $\mathrm{CO}, \mathrm{NMVOCs}$, and $\mathrm{SO}_{x}$ are considered as dependent variables respectively; Asymptotic standard errors are reported in parentheses; *, **, and ${ }^{\star \star \star}$ indicate significance at 10,5 , and $1 \%$ levels.

32 The constant term $\lambda_{0}$ in eq. [6] is again positive and statistically significant. 
At aggregate level, our estimates suggest that, if we consider only positive values of $T$, the turning point of the EKC is firstly an increasing function of technological progress and then the trend reverses. In fact, from the first derivative of eq. [6] with respect to $T$, we find that it increases if $T$ lies in the interval $\left[0,-\frac{2 \lambda_{2}}{3 \lambda_{3}}\right]$ and the opposite holds if $T>-\frac{2 \lambda_{2}}{3 \lambda_{3}}$. Consequently, the effect of technology on the EKC depends on the level of innovation of the economy. This conclusion is in line with some recent theoretical papers which demonstrate that new technologies sometimes increase, and sometimes decrease pollution (see, among others, Smulders, Bretschger, and Egli 2011). In particular, according to our estimates for Italy, there is a negative correlation between the turning point of the EKC and technological progress only for a high level of technology. This implies that, at aggregate level and despite the existence of the EKC, when the level of technology is low, policy making should pay more attention to the environment, since an increase in R\&D expenditure has negative effects in terms of environmental quality. This result is particularly interesting as it conflicts with mainstream thinking in the EKC literature, where, if the EKC is verified, economic growth alone is the solution to environmental problems and doing nothing about them appears to be the best policy.

\subsection{The EKC in Italy: a final overview}

In this paper we have proved the existence of the EKC both at regional and at aggregate levels. This finding is particularly interesting especially in the light of the profound structural change which has characterized the Italian economy in the last 30 years. In fact, at aggregate level, the shares of agricultural and industry sectors on value added shift respectively from 4 and $26 \%$ in 1980 to 2 and $19 \%$ in 2010 . On the other hand, services more than triple in the same period, rising from 24 to $73 \%$. $^{33}$

These dynamics are accompanied by big changes in the energy sector. Consumption of primary energy increases by 19\% between 1990 and 2008. However, starting from 1973 and analogously to the most industrialized countries, Italy has observed a progressive decline in energy intensity. This trend is particularly marked in the most recent years; energy intensity, computed as tons of oil equivalent per euro of value added, dropped by $4.11 \%$ in the years $2005-$ 2008 (IEA 2009). ${ }^{34}$ Energy efficiency improvements and the process of structural

33 The same trends are also observed at regional level.

34 This indicator shows strong differences across regions. On average it is equal to 172 in the Southern regions of Italy in the years 1995-2008 (and equal to 223 in Italian Islands), while lower values are recorded in the Central and Northern regions (94 and 108 respectively). 
economic change are the principal determinants of this fall. Furthermore, this evidence is also accompanied by a decline in oil consumption, particularly marked in the period 1973-1998, when oil consumption per GDP falls from 3.7 to 1.7 , because of the switching to other fuels together with the decline in energy per unit of output (IEA 2009).

This industrial reconstruction has been coupled with a huge increase in transportation, where the use of oil is currently more intense despite the relevant diffusion of fuels alternative to gasoline in the last decades. In fact, natural gas has increased its share of total energy consumption, rising from 26 to $40 \%$ in 1990 and 2008 (IEA 2009). This last trend has important consequences especially in the transport sector, where natural gas can be applied to a wide range of vehicles such as passenger cars, buses, and off-road transportation (marine-cargo ships, airplanes, and locomotives), with important benefits in terms of lower emissions of many local air pollutants, like these investigated in this paper.

The process of energy substitution toward a more intensive use of natural gas and electricity in this country has also been favored by technological progress, as noted by Morana (2000). This is also confirmed by the recent efforts in the oil industry to make new investments in order to satisfy the increasing demand for cleaner fuel consumption and lower sulfur contents (IEA 2009). Moreover, an important opportunity for reducing energy consumption in the Italian energy market is represented by renewable resources, whose development is principally promoted at regional level, as stated in the Italian Law no. 10/1991 (on this point see also Magnani and Vaona 2013).

Finally, in this sub-section, we found that the profound structural change of the Italian economy in the last 30 years, characterized by decreasing shares of agricultural and industry on value added and an extraordinary increase of the service sector, has been accompanied by important changes in the energy market, where, despite the rise of energy consumption, energy efficiency has improved and the development of alternative energy resources has also been incentivized. Furthermore, innovation has played an important role in these processes. All these phenomena are in line with the theoretical assumptions about the existence of the EKC and further strengthen the empirical results discussed in the previous sections.

\section{Conclusions and policy implications}

In this paper we analyze the EKC hypothesis for three air pollutants, CO, NMVOCs, and $\mathrm{SO}_{x}$, in a new dataset based on the 20 regions of Italy published by ISPRA (2010 edition). We use a new formulation of the EKC provided for the first time by 
Bradford et al. (2005), which overcomes some econometric problems related to the traditional functional form of the EKC. Given that, from a theoretical point of view, different papers demonstrate that the relationship between economic growth and environmental quality is closely related to technological progress (Andreoni and Levinson 2001; Chimeli and Braden 2005; Brock and Taylor 2010; and Smulders, Bretschger, and Egli 2011), we extend Bradford et al. (2005) model in order to explicitly study the role of technological progress on the EKC and on its turning point. In the literature there is widespread consensus about the importance of technology in the EKC, but no firm conclusion about how technology influences the turning point of the EKC (Chimeli 2007). We therefore hypothesize a very general cubic relationship between the turning point of the EKC and innovation, without imposing a priori any assumptions about the signs of the coefficients of interest, which are a question to be addressed empirically.

A methodology similar to Leitão (2010) is used. Innovation influences the EKC directly and indirectly, given its close relationship with income. A preliminary estimate of GDP is therefore made in order to capture the influence of technological progress on this variable. Fitted values of per capita income are then used to estimate EKC. Our results confirm the validity of the EKC in the 20 regions of Italy for the three air pollutants considered. Furthermore, in line with previous theoretical findings, technological progress is confirmed as a relevant factor in estimating the EKC. In fact, our hypothesis of the influence of innovation on the EKC turning point is validated and a negative relationship is identified. This implies that a sort of "environmental catching up" occurs: the more innovative a country (or a region), the lower the level of per capita income at which pollution begins to decrease. Robustness checks are also performed. They confirm that technological progress negatively influences the EKC, and a general cubic relationship emerges especially in the case of NMVOCs and when quantile regressions are computed.

Finally, the problem is re-investigated using an alternative dataset based on time series data related to the aggregate national economy instead of regions. The existence of the EKC is again verified, and it is shown that technology has a different impact on the EKC according to the regional case. In fact, when the level of innovation is low, the turning point of the EKC is an increasing function of technological progress, but when high levels of technology are reached, the trend reverses. This implies that new technologies sometimes increase and sometimes decrease pollution. We also demonstrate that the structural change of the Italian economy observed in the last decades, together with a process of energy substitution toward a more efficient use of natural resources, has played an important role in determining the inverse-U-shaped relationship between economic growth and environmental degradation. 
These results have important implications in terms of policy. In general, previous literature on the EKC has suggested that economic growth alone is the solution to all environmental problems, and consequently doing nothing about the environment is the best policy. In this paper, we empirically demonstrate that technology is the driving force behind the existence of the EKC. Consequently, when the policymaker promotes innovation, she also has to consider its impact on the environment. In particular, while at regional level we have demonstrated that technological progress has always positive effects in terms of environmental quality, at national level, greater attention to the environment is instead especially required for low levels of technology (and income), in order to counteract their negative influence in terms of pollution. In this last specific case, the policymaker should promote policies with the twofold aim of fostering innovation and preserving the environment. To the best of our knowledge, the Eco-Innovation Plan is one of the most recent ambitious attempt with the aim to "focus on boosting innovation that results in or aims at reducing pressures on the environment and on bridging the gap between innovation and the market" (European Commission 2011, 1).

Furthermore, in the light of the subsidiary and proportionality principles, the policymaker should also consider that an action taken at regional or local level is more effective. Legislative Decree no. 112 of 31 March 1998 attributes to the Italian regions a high degree of autonomy in terms of innovation and industrial policies. In this way, regions become an important driver of the promotion of applied research, technological transfer programs, and projects (see IEA 2009). This is also in line with the most recent European Directives, which emphasize that the "main competence to foster innovation often lies at regional level" (European Commission 2006, 16). It is also worth noticing that regions play a key role in environmental problems as confirmed by the European Directive 1999/13/EC and by the huge amount of funds (11.2\% of an entire budget of EUR 35.6 billion) designated by the European Regional Development Fund for environmental protection and risk prevention during the most recent years. Our results indicate that the relationship between technology and the turning point of the EKC is always negative at regional level. Consequently, they support the idea that regional policies for innovation promote not only economic growth but also have positive effects on the environment. It is important to note that the impact of technology on the EKC differs slightly between types of pollutant, so the policymaker also needs to accompany these policies with specific actions for the type of emissions to be lowered. For example, the European Directive 1999/13/EC on the limitation of emissions of volatile organic compounds due to the use of organic solvents, which came into force in Italy with Legislative Decree 152/2006, assigns the jurisdiction of atmospheric 
emissions to regions (See Ministry of Environment and Protection of Land and Sea 2007).

To conclude, the complexity of innovation and research policies requires a new political approach based on complementary policies at regional and national level, given also the increasing importance of regions in competitiveness and economic growth. In this context, the Pro INNO Europe constitutes a good example of the most recent efforts of the European Commission in offering "a platform that brings together regional and national policymakers with a view to facilitating trans-national cooperation in areas of common interest" such as innovation and the environment (see European Commission 2006, 16).

Acknowledgments: The author would like to thank Mario Menegatti, two anonymous referees, and the seminar participants of University of Parma for useful comments and suggestions. The usual disclaimers apply.

\section{Appendix}

In this appendix, we provide two microfoundations of eq. [5]. The first approach is based on the theoretical paper of Andreoni and Levinson (2001). Andreoni and Levinson (2001) consider a single agent economy, where preferences are represented by the following bivariate utility function:

$$
U(C, P)=C-P,
$$

where $U(C, P)$ is linear and additive in the consumption of a private good $(C)$ and pollution $(P)$. Pollution positively depends on consumption and negatively on the environmental effort $(E)$ as defined by the following condition:

$$
P(C, E)=C-C^{\phi} E^{\gamma} .
$$

The first term on the right-hand side of Condition [13] is gross pollution before abatement, while the second term is abatement activities. We assume that $\phi+\gamma>1$.

After substituting eq. [13] into eq. [12], the utility function becomes

$$
U(C, E)=C^{\phi} E^{\gamma}
$$

and consequently the agent's maximization problem is a standard Cobb-Douglas problem solved by maximizing Condition [14] subject to the budget constraint $Y=C+E$. 
The optimal consumption and environmental effort choices are given by the following two standard Cobb-Douglas conditions:

$$
C^{*}=\frac{\phi}{\phi+\gamma} Y
$$

and

$$
E^{*}=\frac{\gamma}{\phi+\gamma} Y
$$

The optimal level of pollution is then given by substituting eqns [15] and [16] into eq. [13]:

$$
P^{*}(Y)=\frac{\phi}{\phi+\gamma} Y-\left(\frac{\phi}{\phi+\gamma}\right)^{\phi}\left(\frac{\gamma}{\phi+\gamma}\right)^{\gamma} Y^{\phi+\gamma} .
$$

Assume now that $\phi=1$ and $\gamma=1$. These hypotheses satisfy the constraint $\phi+\gamma>1$. We easily obtain that eq. [17] exactly indicates the quadratic inverse$\mathrm{U}$-shaped relationship between pollution and income proposed by eq. [1], since parameters $b=\frac{\phi}{\phi+\gamma}$ and $c=-\left(\frac{\phi}{\phi+\gamma}\right)^{\phi}\left(\frac{\gamma}{\phi+\gamma}\right)^{\gamma}$ are positive and negative respectively. Given that eq. [5] is directly derived from eq. [1], the model proposed by Andreoni and Levinson (2001) also constitutes a microfoundation of eq. [5].

Finally, it is interesting to note that analogous conclusions are also reached if we consider a bivariate Constant Relative Risk Aversion utility function defined as follows:

$$
U(C, E)=\frac{C^{(1-\alpha)} E^{\beta(1-\alpha)}}{1-\alpha} .
$$

In this case, the agent's maximization problem is directly solved by maximizing Condition [18] subject to the budget constraint $Y=C+E$. After usual computations, we find that

$$
C^{* *}=\frac{1}{1+\beta} Y
$$

and

$$
E^{* *}=\frac{\beta}{1+\beta} Y .
$$

Finally, we then substitute eqs [19] and [20] into eq. [13]. We obtain that

$$
P^{* *}(Y)=\frac{1}{1+\beta} Y-\left(\frac{1}{1+\beta}\right)^{\phi}\left(\frac{\beta}{1+\beta}\right)^{\gamma} Y^{\phi+\gamma}
$$


where, under the assumptions that $\phi=1$ and $\gamma=1$, we find that eq. [21] also constitutes a microfoundation of eq. [5], given that the parameters $b=\frac{1}{1+\beta}$ and $c=-\left(\frac{1}{1+\beta}\right)^{\phi}\left(\frac{\beta}{1+\beta}\right)^{\gamma}$ are positive and negative respectively.

\section{References}

Akbostancı, E., S. Türüt-Asik, and İ. Tunç. 2009. "The Relationship between Income and Environment in Turkey: Is There an Environmental Kuznets Curve?” Energy Policy 37:861-67.

Aldy, J. E. 2005. “An Environmental Kuznets Curve Analysis of U.S. State-Level Carbon Dioxide Emissions." The Journal of Environment and Development 14:48-72.

Andreoni, J., and A. Levinson. 2001. "The Simple Analytics of the Environmental Kuznets Curve." Journal of Public Economics 80:269-86.

Ang, J. B. 2007. “ $\mathrm{CO}_{2}$ Emissions, Energy Consumption, and Output in France." Energy Policy 35:4772-78.

Bianchi, C., and M. Menegatti. 2008. "Neoclassical versus Technological Convergence: Some Evidence from the Recent Experience of the Italian Regions." Rivista Internazionale di Scienze Sociali 3:271-87.

Bradford, D. F., R. Fender, S. H. Shore, and M. Wagner. 2005. “The Environmental Kuznets Curve: Exploring a Fresh Specification.” Contributions to Economic Analysis and Policy 4(1): Article 5.

Brock, W. A., and M. S. Taylor. 2010. “The Green Solow Model.” Journal of Economic Growth 15:127-53.

Carson, R. T., Y. Jeon, and D. R. McCubbin. 1997. “The Relationship between Air Pollution Emissions and Income: US Data.” Environment and Development Economics 2:433-50.

Caselli, F., G. Esquivel, and F. Lefort. 1996. "Reopening the Convergence Debate: A New Look at Cross-Country Growth Empirics.” Journal of Economic Growth 1:363-89.

Chernozhukov, V., I. Fernández-Val, and A. Galichon. 2010. "Quantile and Probability Curves without Crossing." Econometrica 78:368-86.

Chimeli, A. B. 2007. “Growth and the Environment: Are We Looking at the Right Data?" Economics Letters 96:89-96.

Chimeli, A. B., and J. B. Braden. 2005. "Total Factor Productivity and the Environmental Kuznets Curve." Journal of Environmental Economics and Management 49:366-80.

Cialani, C. 2007. "Economic Growth and Environmental Quality: An Econometric and a Decomposition Analysis." Management of Environmental Quality: An International Journal 18:568-77.

Dinda, S. 2004. “Environmental Kuznets Curve Hypothesis: a Survey.” Ecological Economics 49:431-55.

Dowrick, S., and M. Rogers. 2002. "Classical and Technological Convergence: Beyond the Solow-Swan Growth Model.” Oxford Economic Papers 54:369-85.

European Commission. 1999. Towards Environmental Pressure Indicators for the EU. Luxembourg: (Eds.) European Commission/Eurostat.

European Commission. 2006. "Putting Knowledge into Practice: A Broad-Based Innovation Strategy for the EU.” Brussels, 13.09.2006. 
European Commission. 2010a. "Europe 2020: A Strategy for Smart, Sustainable and Inclusive Growth." Brussels, 3.03.2010.

European Commission. 2010b. "The CAP towards 2020: Meeting the Food, Natural Resources and Territorial Challenges of the Future." Brussels, 18.11.2010.

European Commission. 2011. "Innovation for a Sustainable Future - The Eco-Innovation Action Plan (Eco-AP).” Brussels, 15.12.2011.

Flores, C. A., A. Flores-Lagunes, and D. Kapetanakis. 2013. "Lessons from Quantile Panel Estimation of the Environmental Kuznets Curve.” Econometric Reviews in press, 33:815-853.

Fodha, M., and O. Zaghdoud. 2010. "Economic Growth and Pollutant Emissions in Tunisia: An Empirical Analysis of the Environmental Kuznets Curve.” Energy Policy 38:1150-56.

Fosten, J., B. Morley, and T. Taylor. 2012. "Dynamic Misspecification in the Environmental Kuznets Curve: Evidence From $\mathrm{CO}_{2}$ and $\mathrm{SO}_{2}$ Emissions in the United Kingdom." Ecological Economics 76:25-33.

Friedl, B., and M. Getzner. 2003. "Determinants of $\mathrm{CO}_{2}$ Emissions in a Small Open Economy." Ecological Economics 45:133-48.

Gangadharan, L., and M. R. Valenzuela. 2001. "Interrelationships between Income, Health and the Environment: Extending the Environmental Kuznets Curve Hypothesis." Ecological Economics 36:513-31.

Ghisetti, C., and F. Quatraro. 2013. "Beyond Inducement in Climate Change: Does Environmental Performance Spur Environmental Technologies? A Regional Analysis of Cross-Sectoral Differences." Ecological Economics 96:99-113.

Grossman, G. M., and A. B. Krueger. 1991. "Environmental Impacts of the North American Free Trade Agreement.” NBER Working Paper, 3914.

Grossman, G. M., and A. B. Krueger. 1995. "Economic Growth and the Environment." Quarterly Journal of Economics 110:353-77.

He, J., and P. Richard. 2010. "Environmental Kuznets Curve for $\mathrm{CO}_{2}$ in Canada." Ecological Economics 69:1083-93.

IEA [International Energy Agency]. 2009. Energy Policies of IEA Countries: Italy 2009 Review. Paris: OECD/International Energy Agency.

Islam, N. 1995. "Growth Empirics: A Panel Data Approach.” The Quarterly Journal of Economics 110:1127-70.

Iwata, H., K. Okada, and S. Samreth. 2010. "Empirical Study on the Environmental Kuznets Curve for $\mathrm{CO}_{2}$ in France: The Role of Nuclear Energy." Energy Policy 38:4057-63.

Iwata, H., K. Okada, and S. Samreth. 2012. "Empirical Study on the Determinants of CO2 Emissions: Evidence from OECD Countries.” Applied Economics 44:3513-19.

Jalil, A., and S. F. Mahmud. 2009. "Environmental Kuznets Curve for $\mathrm{CO}_{2}$ Emissions: A Cointegration Analysis for China." Energy Policy 37:5167-72.

Kahn, M. E. 1998. “A Household Level Environmental Kuznets Curve.” Economics Letters 59:269-73.

Khanna, N. 2002. "The Income Elasticity of Non-Point Source Air Pollutants: Revisiting the Environmental Kuznets Curve." Economics Letters 77:387-92.

Koenker, R. 2005. Quantile Regression. New York: Cambridge University Press.

Komen, M. H. C., S. Gerking, and H. Folmer. 1997. "Income and Environmental R\&D: Empirical Evidence from OECD Countries." Environmental and Development Economics 2:505-15.

Kuznets, S. 1955. "Economic Growth and Income Inequality." American Economic Review 45:1-28. 
Leitão, A. 2010. "Corruption and the Environmental Kuznets Curve: Empirical Evidence for Sulfur." Ecological Economics 69:2191-201.

Lekakis, J. N. 2000. "Environment and Development in a Southern European Country: Which Environmental Kuznets Curves?" Journal of Environmental Planning and Management 43:139-53.

Leonida, L., C. Petraglia, and L. R. Murillo-Zamorano. 2004. "Total Factor Productivity and the Convergence Hypothesis in the Italian Regions." Applied Economics 36:2187-93.

List, J. A., and C. A. Gallet. 1999. "The Environmental Kuznets Curve: Does One Size Fit All?" Ecological Economics 31:409-23.

Magnani, N., and A. Vaona. 2013. "Regional Spillover Effects of Renewable Energy Generation in Italy." Energy Policy 56:663-71.

Mazzanti, M., A. Montini, and R. Zoboli. 2008. "Environmental Kuznets Curves for Air Pollutant Emissions in Italy: Evidence From Environmental Accounts (NAMEA) Panel Data." Economic Systems Research 20:277-301.

Millimet, D. L., J. A. List, and T. Stengos. 2003. "The Environmental Kuznets Curve: Real Progress or Misspecified Models?" The Review of Economics and Statistics 85:1038-47.

Ministry of Environment and Protection of Land and Sea (Ministero dell'Ambiente e della Tutela del Territorio e del Mare). 2007. Relazione della Direttiva 1999/13/CE sulla Limitazione delle Emissioni di Composti Organici Volatili Dovute all'Uso di Solventi Organici in Talune Attivitá E Taluni Impianti. http://www.minambiente.it/pagina/emission

Morana, C. 2000. "Modelling Evolving Long-Run Relationships: an Application to the Italian Energy Market." Scottish Journal of Political Economy 47:72-93.

Nasir, M., and F. U. Rehman. 2011. "Environmental Kuznets Curve for Carbon Emissions in Pakistan: An Empirical Investigation.” Energy Policy 39:1857-64.

Orubu, O. C., and D. G. Omotor. 2011. "Environmental Quality and Economic Growth: Searching for Environmental Kuznets Curves for Air and Water Pollutants in Africa." Energy Policy 39:4178-88.

Panayotou, T. 1997. "Demystifying the Environmental Kuznets Curve: Turning a Black Box into a Policy Tool." Environmental and Development Economics 2:469-84.

Park, S., and Y. Lee. 2011. "Regional Model of EKC for Air Pollution: Evidence from the Republic of Korea." Energy Policy 39:5840-49.

Roca, J., E. Padilla, M. Farrè, and V. Galletto. 2001. "Economic Growth and Atmospheric Pollution in Spain: Discussing the Environmental Kuznets Curve Hypothesis." Ecological Economics 39:85-99.

Saboori, B., J. Sulaiman, and S. Mohd. 2012. "Economic Growth and $\mathrm{CO}_{2}$ Emissions in Malaysia: A Cointegration Analysis of the Environmental Kuznets Curve.” Energy Policy 51:184-191.

Selden, T. M., and D. Song. 1994. "Environmental Quality and Development: is There a Kuznets Curve for Air Pollution Emissions?" Journal of Environmental Economics and Management 27:147-62.

Shafik, N., and S. Bandyopadhyay. 1992. "Economic Growth and Environmental Quality: Time Series and Cross-Country Evidence.” Background Paper for the World Development Report. The World Bank, Washington, DC.

Smulders, S., L. Bretschger, and H. Egli. 2011. "Economic Growth and the Diffusion of Clean Technologies: Explaining Environmental Kuznets Curves." Environmental and Resource Economics 49:79-99.

Stern, D. I. 1998. "Progress on the Environmental Kuznets Curve?" Environment and Development Economics 3:173-96. 
Stern, D. I. 2004. "The Rise and Fall of the Environmental Kuznets Curve." World Development 32:1419-39.

Stock, J. H., and M. Yogo. 2005. "Testing for Weak Instruments in Linear IV Regression.” In Identification and Inference for Econometric Models: Essays in Honor of Thomas Rothenberg, edited by D. W. K. Andrews and J. H. Stock, 80-108. Cambridge: Cambridge University Press.

Suri, V., and D. Chapman. 1998. "Economic Growth, Trade and the Environment: Implications for the Environmental Kuznets Curve." Ecological Economics 25:195-208.

Vincent, J. R. 1997. "Testing for Environmental Kuznets Curves within a Developing Country." Environment and Development Economics 2:417-31.

Wooldridge, J. M. 2002. Econometric Analysis of Cross Section and Panel Data. Cambridge, MA: MIT Press. 